Ilmenau University of Technology

Institute of Economics

Ilmenau Economics Discussion Papers, Vol. 25, No. 123

Stars in Social Media:

New Light Through Old Windows?

Sophia Gaenssle \& Oliver Budzinski

April 2019

Institute of Economics

Ehrenbergstraße 29

Ernst-Abbe-Zentrum

D-98 684 Ilmenau

Phone 03677/69-4030/-4032

Fax 03677/69-4203

http://www.wirtschaft.tu-ilmenau.de

ISSN 0949-3859 


\title{
Stars in Social Media: New Light Through Old Windows?
}

\section{Sophia Gaenssle ${ }^{\#}$ \& Oliver Budzinski*x}

\begin{abstract}
We review the economics of superstars, originally developed for stars in traditional media, and discuss whether they are applicable for the (allegedly) novel phenomenon of stars in social media (influencer, micro-celebrities). Moreover, we analyse potentially new factors for creating social media superstardom that may be special to the nature of social media. Our overall result is that the economics of superstars, like the role of talent, market concentration effects, MacDonald-style and Adler-style effects, remain applicable and relevant for social media stars. In line with this assessment, we find that several (allegedly) new star factors in social media, like user-generated content, prosumption, disappearance of gatekeepers and authenticity, turn out to be only partly applicable or just slightly different to traditional concepts. However, algorithm management and upload strategies represent novel success factors relevant for social media superstardom that are not captured by traditional superstar theories.
\end{abstract}

Keywords: social media, digital media, popularity, superstars, cultural economics, media economics, influencer, micro-celebrities, creators, user-generated content, prosumer, algorithm management, YouTube, Instagram, entertainment markets

JEL-Codes: L82, Z10, L13, L15, L86, D43, D83, F23, M21, D91, L26

M.Sc., Institute of Economics, Ilmenau University of Technology, Germany, Email: sophia.gaenssle@tuilmenau.de.

Professor of Economic Theory, Institute of Economics and Institute of Media and Mobile Communications, Ilmenau University of Technology, Germany, Email: oliver.budzinski@tu-ilmenau.de.

We thank the participants of the 52 ${ }^{\text {nd }}$ Hohenheimer Oberseminar (Weimar, April 2019) as well as Christopher Buschow and Barbara Ann Güldenring for valuable comments on earlier versions of the paper. Furthermore, we thank Elena Willi, Milena Wehner and Alina Ahrens for valuable editorial assistance. 


\section{Table of Contents}

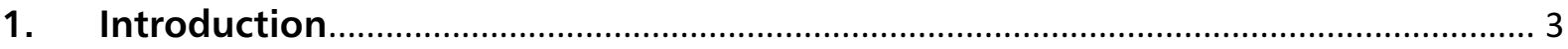

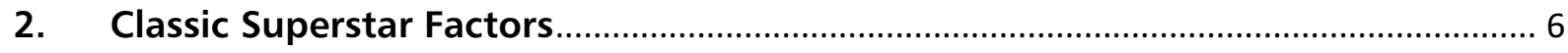

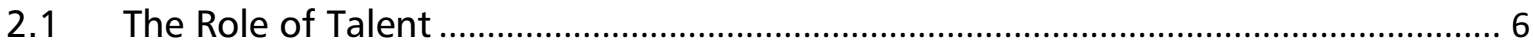

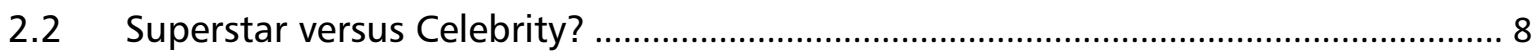

2.3 Economies of Scale and Market Power ......................................................... 9

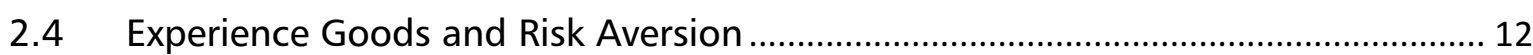

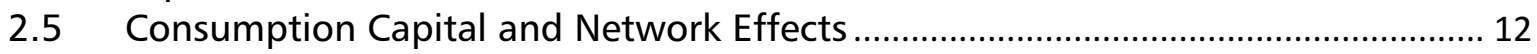

2.6 Summary: The Role of the Old Windows.............................................................. 14

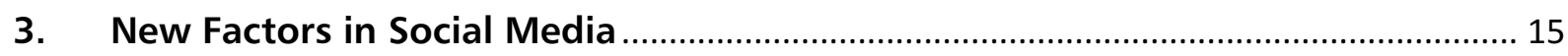

3.1 User Generated Content, Prosumption, and Platform Economics .......................... 15

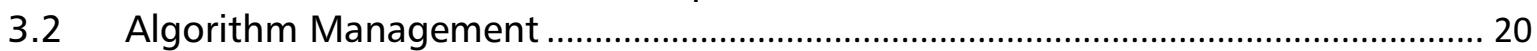

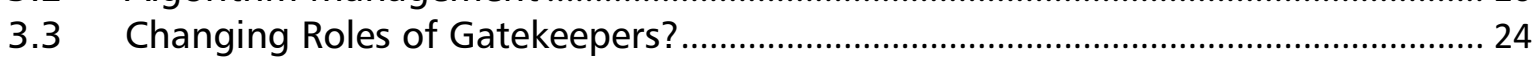

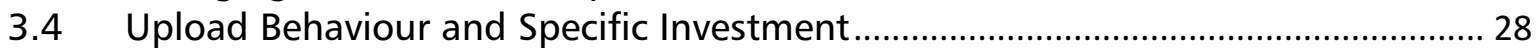

3.5 Authenticity and Accessibility: Ordinary People as Stars and Fan-Star Interaction31

4. Implications and Conclusion: The Role of the New Light ...................................... 36

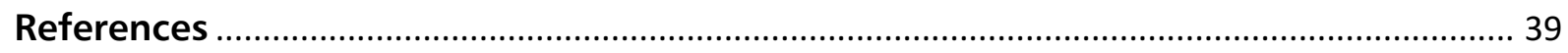

Appendix 


\section{Introduction}

Social media stars (also called: influencers, creators, micro-celebrities, online stars, etc.) are content providers on social media platforms, who become very popular with considerable reach and big audiences, as e.g. the YouTube gamer DanTDM (Daniel Middleton) with 19 million subscribers (July 2018; YouTube 2018a) or Instagram fitness-star Kayla Itsines with 9.8 million subscribers (July 2018; Instagram 2018). Although social media content provider or "influencer" is not yet broadly established as a "proper profession", the income of these stars underlines the professional quality and commercial dimension of the business. According to Forbes (Robehmed \& Berg 2018), the top 10 YouTube stars earned an aggregated 180.5 million US dollars in 2018. Daniel Middleton alone ranks the highest-paid gaming star with an estimated income of 18 million US dollars. Yet, not only the economic power of social media stars makes it an interesting and relevant topic for academic research; also their social and cultural influence is notable. The stars grow to become opinion leaders with considerable influence on public opinion and cultural development.

Different names are used to describe online stardom. In the media and in non-academic fields these stars are mostly called influencers. This refers mainly to promotional aspects of the star phenomenon, which is why this term is often found in a marketing context along with the description celebrity endorser (Jin \& Phua 2014, Veirman et al. 2017, Xiao et al. 2018). In communication and media studies, they are often referred to as micro-celebrities (Senft 2008, Marwick 2010, 2015). The platforms (inter alia, YouTube and Instagram) call them creators, as they create contents for their audience. In our research, we use the term social media stars because it is a neutral and comprehensive description of the phenomenon, covering all aspects of the star personality without putting too much weight on marketing, influencing or manipulative characteristics that some (but not all) social media stars are defined by. The term social media stars solely describes stardom that arises on social media platforms. These platforms have different characteristics and services. As stardom arises with the provision of content, we focus on so-called content communities (inter alia, YouTube for videos, Instagram for pictures and Twitter for text content) rather than 
so-called communication and networking communities (for instance, Facebook or Linkedln). ${ }^{1}$

Table 1 shows the most popular platforms and number of social media stars in relation. A complete and detailed overview of the most popular content communities for videos, pictures and text/blogging-contents (including information on revenues, number of content uploads, number of users, and superstar categories) is provided in the appendix (see Table 4).

Table 1: Overview Platforms and Number of Social Media Stars

\begin{tabular}{|l|l|l|}
\hline Platform & Parent Company & Number of Top Stars ${ }^{2}$ \\
\hline YouTube & Google LLC & Total: $\mathbf{4 6}$ \\
\hline Vimeo & InterActiveCorp & Total: $\mathbf{0}$ \\
\hline Twitch & $\begin{array}{l}\text { Amazon.com, Inc. } \\
\text { (Twitch Interactive, Inc.) }\end{array}$ & Total: $\mathbf{2}$ \\
\hline MySpace & Time Inc. & Total: $\mathbf{1}$ \\
\hline Instagram & Facebook Inc. & Total: 13 \\
\hline Pinterest & Cold Brew Labs, Inc. & Total: $\mathbf{1}$ \\
\hline Twitter & Twitter Inc. & Total: $\mathbf{4}$ \\
\hline Tumblr & $\begin{array}{l}\text { Oath Inc. } \\
\text { (Until } 2017: \text { Yahoo) }\end{array}$ & Total: $\mathbf{0}$ \\
\hline
\end{tabular}

Castillo (2018), Chatterjee \& Aripaka (2018), Honsel (2018), Vimeo (2018), Winkler (2015), Wuttig (2018)

Table 1 demonstrates, the leading platforms for social media usage and fame are YouTube and Instagram. Therefore, for illustrative purposes, we focus on these most popular ones for the present analysis - a choice that, however, should not exclude the possibility of emerging new platforms and changes in the market structure in the future. Although research on blogging and text communities might also reveal interesting insights, it is the audio-visual content on social media sites that is a decisive

See Kaplan \& Haenlein (2010) and Detel (2017: 119) for further differentiation between social media platforms.

2 According to Forbes (2018) top ten rankings per category, excluding pets, private blogs and vlogs. 
factor in creating the most predominant social media stars. This is why we exclude blogging and text communities from our analysis.

Furthermore, different kinds of popular stars and accounts have to be distinguished. Firstly, social media stars (in the narrow sense) are content providers whose "fame is native to social media" (Marwick 2015: 337). This excludes star personalities like musicians, actors or athletes, who gained their prominence outside of the social media system, but also run successful social media accounts. Secondly, viral contents (like one-hit wonders) are excluded. The star character in our research is connected to the person operating the social media account. Content without personal connection, such as popular animal videos, trailers or individual viral videos, are not included in our research, along with non-commercial accounts or contents, private blogs or websites. We analyse sustainable content providers with considerable star success, who evolve to become superstars in their social media category and are not primarily present in the traditional offline world (e.g. gaming stars, fitness stars, how-to stars). Therefore, not the early stages of audience creation and attention seeking are the main focus of this paper, but the final steps of professionalisation from stardom to superstardom.

The social media star phenomenon draws a lot of attention and is widely discussed in media and society. On the one hand, its novelty and, in particular, its great influence on consumers are emphasised (Nouri 2018), significantly departing from the traditional, "offline" superstar phenomenon as described by, for instance, Rosen (1981) and Adler (1985). On the other hand, Budzinski \& Gaenssle (2018) find support for traditional economic superstar theories in their empirical analysis of YouTube-stars. This begs the question: does social media stardom represent a novel phenomenon with respect to its economic mechanisms or is it rather characterised by new light shining through old windows? In this paper, we address this research question by conceptually analysing traditional and potentially novel elements of the superstar phenomenon. In doing so, we identify a number of areas where social media stars resemble the traditional superstar phenomenon from an economic perspective (see chapters $2.1,2.3,2.4$ ). Nevertheless, we also derive a number of star mechanisms that considerably depart from traditional theory like algorithm management and upload behaviour strategies (see chapters 3.2, 3.4). We disenchant major parts 
of the "influencer-uniqueness", as some developments seem different and novel, but the underlying mechanisms stay de facto the same, for instance, the changing role of gatekeepers, strategic intimacy and authenticity, and star-fan interaction (see chapters 3.3, 3.5). Eventually, we shed light on some popular buzzwords like user generated content or prosumers.

The paper is structured as follows. Firstly, Section 2 reviews relevant aspects of the classic economic theory on superstars. Secondly, Section 3 outlines extensions to this theory, which are not subject to the previous economic analysis on superstars but instead represent novel aspects of the digital world of social media stars like algorithm management or upload behaviour. Section 4 provides some concluding thoughts.

\section{Classic Superstar Factors}

\subsection{The Role of Talent}

The paper "The Economics of Superstars" by Rosen (1981) is the groundwork for the modern economic theory of superstars and identifies a fundamental aspect of stardom: small differences in talent generate significant and over-proportional differences in income. "Lesser talent is often a poor substitute for greater talent" (Rosen 1981: 846). A sum of various mediocre performances does not add up to one outstanding performance. Thus, the imperfect substitution of different levels of talent drives superstar effects.

In theory this aspect makes up a core element of superstar power; however, objective measures of talent, which can be defined in so many different ways, have proven to be challenging in empirical studies (Krueger 2005, Franck \& Nüesch 2012). What characterises "real" talent? What kind of talent is necessary to succeed in a market? Different sciences have different understandings of talent, e.g. sports sciences differentiate the innate talent of an individual from the skills and proficiency that can be acquired and developed by training. The combination of both yields the performance of an athlete. Since measuring performance in many sports disciplines is possible (as, for instance, the speed of a sprinter) and despite the difficulties in disentangling 
talent and skills, most talent-related empirical studies on superstars relate to sports (inter alia, Kahn 2000, Rosen \& Sanderson 2001, Romer 2006). ${ }^{3}$

However, the evaluation of the performance of entertainment stars is more complex (Schulze 2003, Franck \& Nüesch 2012) and a distinction of talent and skills appears to be neither helpful nor feasible. Hamlen (1991), one of the few studies attempting to measure talent in entertainment media, measures the "harmonic quality" of a singer's voice according to music science as a proxy for talent and analyses its influence on charts success. He finds that record sales under-proportionally increase with harmonic voice quality. However, the importance of the subjective perception of a performance by the audience (i.e. they feel entertained) as well as the inability of the audience to recognise "true" talent (Franck \& Nüesch 2007) casts doubt on whether externally-measured talent really matters. As a consequence, Gergaud et al. (2012) analyse the influence of perceived talent, intelligence and beauty according to a survey of 49 celebrities from different categories of entertainment industries. They find that perceived talent and perceived intelligence are more important than perceived beauty. Budzinski et al. (2019) disentangle different dimensions of entertainment talent in popular music, including externally-measurable dimensions from music science (like the composition scheme, instrumentation or the length of the intro) and subjective audience impressions (like charisma, softness, image, originality or intensity). Somewhat generalised, they find that subjective dimensions are more relevant to success than objective ones. Therefore, in entertainment markets, the core talent in a particular field in combination with "soft-skills" (like pleasant appearance and charm) work together and influence the subjective perception of consumers. According to Amegashie (2009), this multidimensional character of competition in entertainment markets actually fuels the utilisation of talent through effort.

Similarly, there is not just one specific talent that can be pointed to concerning social media stars. Instead, most of them are entertainers and, therefore, subject to many facets attributable to an entertainment talent. Gaming stars (so called e-sports) may

However, measuring individual performance in team sports is more difficult: does the number of goals of a striker in (European-style) football, for instance, measures his performance (and talent) or the one of his team and/or the centres with their passes? 
represent an exception; here, a measurement of playing talent (proxied by performance) may be possible. Like in traditional sports, this type of talent may play a relevant role in the superstardom of gamers. Summing up, social media talent is a multidimensional entertainment talent, which is very difficult to exactly specify and delimit for empirical analyses.

\subsection{Superstar versus Celebrity?}

In contrast to "truly" talented stars, celebrities appear to be important, but, in fact, their fame quickly fades after they are hyped by the media. "The celebrity is a person who is known for his well-knownness" (Boorstin 1961: 57). Franck \& Nüesch (2007) distinguish self-made superstars (à la Rosen 1981, Adler 1985, 2006, MacDonald 1988, Borghans \& Groot 1998) from manufactured celebrities (à la Boorstin 1961, Gamson 1994, Marshall 1997, Cowen 2000, Turner 2004). According to their theory, superstars are unique personalities with extraordinary talent who excel in their respective fields. The imperfect substitution of superior talent makes them unique and distinctive, which gives them bargaining power (Rosen 1981, Borghans \& Groot 1998). Celebrities, in contrast, are made and hyped by the media and are interchangeable; thus, they are dependent on media and do not enjoy considerable bargaining power. There is no specific quality attached to celebrities, who mainly fulfil entertainment purposes and are de facto insubstantial.

In reality, however, the difference between superstars and celebrities is not that precise and the ostensible strict boundaries are rather blurred. A successful athlete might also be hyped by the media and reported on concerning his or her private life, whereas a celebrity might also have some talent and success in the long run.

This is what we also find in the social media market. For instance, Marwick (2010, 2015) refers to social media stars as micro-celebrities. "The micro-celebrity practitioner may have a very small number of followers, but is able to inhabit the celebrity subject position through the use of [...] social technologies [...]" (Marwick 2015: 334). In recent years, the social media market developed quickly and, for instance, a fan base of 1.1 billion subscribers to gaming accounts on YouTube (top 225 accounts; Socialblade 2018) can hardly be described as "micro". Nowadays, social media stars have a broad reach and operate on global online platforms. Thus, they have 
outgrown the definition of "micro", which might have been applicable in the beginnings of social media fame.

Furthermore, due to the self-made characteristics of social media stars, the term "celebrity" in its above sketched meaning does not seem to be suitable for social media stars. Virtually all of the current top social media stars did not enjoy instant fame. Quite the contrary, they needed to generate an audience step-by-step in the early stages of their career. To compete in this information-rich market where switching and sampling costs are low and alternative contents "just a click away", they needed to seriously invest into audience building (Budzinski \& Gaenssle 2018) in order to slowly grow into star status. So, on the one hand, the paths towards success of most social media stars rather resemble the self-made superstar type than the celebrity type. On the other hand, referring to the media-made character of celebrities, it can be observed that social media platforms increasingly engage in active star building. Hence, (at least some) social media stars might be "media-made" in the sense of "platform-made" (see also chapter 3.5 on gatekeepers) - and this may become more relevant in the future. Overall, a sharp distinction between self-made superstars and manufactured celebrities does not appear to be particularly helpful for analysing social media stars.

\subsection{Economies of Scale and Market Power}

According to Rosen (1981) another factor, technology, is vital for explaining the market concentration on only the most talented superstars. Typically, high first copy costs of media production are followed by low variable cost of distribution. For digital goods, the cost of reproduction is close to zero - without any notable loss of quality. There is no rivalry in consumption of media content, as it does not get used up by other consumers (Budzinski \& Kuchinke 2019). "The implied scale economy of joint consumption allows relatively few sellers to service the entire market" (Rosen 1981: 847). Nowadays, media contents are just "one click away" and can easily be purchased online. Following Rosen's arguments, for the most talented (social media) star the effort of serving 100 or 100,000 recipients is more or less the same (Rosen 1981: 847). The fixed cost of content generation, e.g. the production of a YouTube 
video or an Instagram picture, is largely independent of the audience size. ${ }^{4}$ Moreover, contents can be spread over various platforms to increase reach. An Instagram picture or video with text, for instance, can also be posted on Twitter.

It can be observed that many social media stars engage in such a multi-homing strategies and operate diverse accounts. The larger the respective audience becomes, the more lucrative the production of content becomes. "The important practical implication is that it is monetarily advantageous to operate in a large overall market, and it is increasingly advantageous the more talented one is" (Rosen 1981: 855). According to Borghans \& Groot (1998), the market size in combination with the market power of unique, non-exchangeable superstars leads to temporary monopolistic power. They argue that, due to the technology and scale effects, only one person is needed to serve the whole market and, thus, the concentration will be on the one with the best performance. In markets with homogeneous goods this could, in fact, lead to the "winner takes it all phenomenon" (Frank \& Cook 2013).

However, in media markets with heterogeneous goods, multi-homing and demand for diversity, this extreme development cannot be expected. Heterogeneous consumer preferences and variety seeking behaviour delimit superstar power. What we actually observe is usually not one single superstar, who controls the market from a monopoly position, but a market concentration on a few top stars accompanied by numbers of medium stars. There are a lot more than just one or two famous rock bands, actresses or YouTube-stars (Schulze 2003). Typically, consumers listen to different bands of the same music genre for instance, and prefer some variety in their social media feeds. Hence, the market structure resembles a close oligopoly of a small number of powerful superstars (accompanied by a lot of less powerful stars who are still not completely irrelevant to the market), rather than a monopoly structure of one dominant superstar.

4 However, if star-fan interaction is important, the cost of communication and interaction increases with output quantities (audience size) (see chapter 3.5). 


\section{Figure 1: Distribution of Subscriptions to YouTube Gaming}

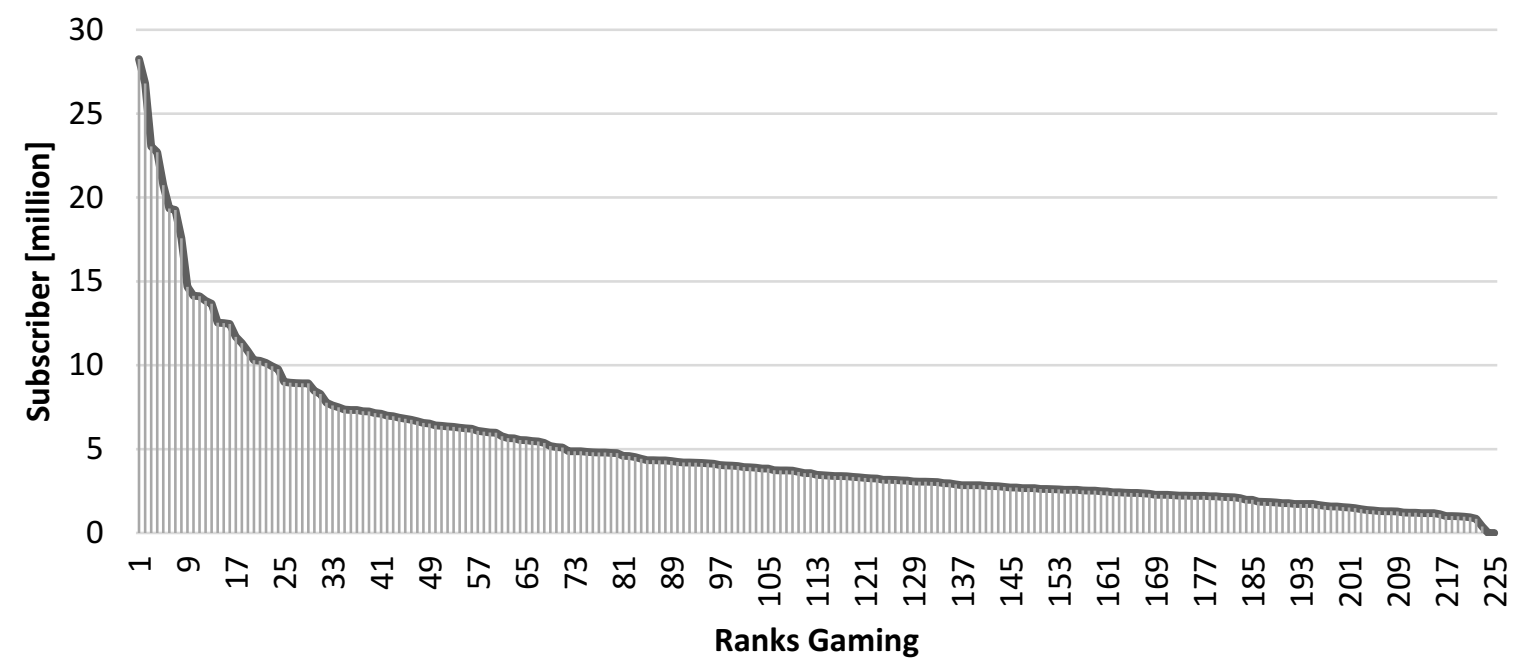

Socialblade (2018)

Social media stars and the markets they are acting in do not substantially differ from traditional entertainment markets in this regard. Figure 1 visualises the superstar phenomenon and the concentration on the few most popular stars in the Gaming sector of YouTube (top 225 accounts, September 2018). It can be observed that the top stars gather a great majority of subscribers. The popularity rapidly decreases and then the decline-rate becomes rather constant after approximately rank 30 . The given technology allows all content-providers to serve a global overall market with heterogeneous goods. Furthermore, scale effects in social media markets can also be related to accounts and not only to single content items (like a single video or picture). When accounts as serial publishers of contents from the same social media star are considered, overall economies of scale are comparatively weakened due to the necessity to constantly upload new content (see also section 3.4). Notwithstanding, the top group prevails despite numerous competitive contents in the (information-rich) social media environment. This shows the superstar character, as described by Rosen, in the modern social media market of YouTube and its inherent tendency towards few most favoured stars. 


\subsection{Experience Goods and Risk Aversion}

MacDonald (1988) developed a dynamic superstar model, which emphasises the role of former success as an explanation for current popularity. Risk-averse consumers prefer known qualities (incumbent stars) over unknown qualities (newcomers) and, thus, tend to stick with the incumbent market players they already know. Consumers can only evaluate the quality of an entertainment good after consumption due to its experience good characteristic. The combination of risk aversion and experience good characteristics leads to entry barriers for newcomers, who will find it difficult to draw the attention of consumers away from established and known stars.

Applying MacDonald's theory to the social media market implies that incumbents on a platform enjoy advantages over newcomers. Their previous success positively influences their current and future success. Empirical studies of YouTube show that the duration in the market is a vital aspect of social media success and YouTube stars of previous periods can maintain their top positions over time (Budzinski \& Gaenssle 2018). So, the path-dependencies of rising stars due to the conservatism of consumers is observable in social media markets as well - despite their young age and still strongly expanding character.

\subsection{Consumption Capital and Network Effects}

Next to talent and former success, the popularity and public status of a star may be a factor of success, according to Adler (1985). In his paper, he expands Rosen's model referring to the specific knowledge of consumers and the accumulation of consumption capital (Stigler \& Becker 1977). The more consumers know about a star and his or her work, the more enjoyment they can derive from further consumption. For instance, previous knowledge of a specific video game makes it easier to follow a gaming star playing it. Adler emphasises three ways to accumulate star-specific knowledge: (i) the direct consumption of his or her work (Stigler \& Becker 1977), (ii) discussion about it with friends and acquaintances, including gossip (commonality effects), (iii) information through media coverage (Adler 2006). The only cost for consumers is the time they spend for direct consumption (if consumption is free of charge) and searching costs to find information about the star and conversation 
partners. Following the most famous and popular star minimises these costs, as he or she is widely known and information is broadly available. "When the artist is popular, it is easier to find discussants who are familiar with her or to find media coverage about her. This is why consumers prefer to consume what others also consume" (Adler 2006: 898). Since consumers prefer the same star and maximise their marginal utility, this results in positive direct network effects and bandwagon effects (Leibenstein 1950). Regarding the high volume and low cost of communication in social media, bandwagon effects are likely to occur. In gaming, for instance, fans of a specific video game can teach each other tricks and necessary skills or discuss technical features and updates. This naturally results in the accumulation of consumption capital and knowledge. Enthusiasts tend to gather around the most famous stars (see Figure 1), who not only provide high quality information/content due to superior talent (Rosen-perspective) but unify people with similar interests (Adler-perspective). It is easy to find like-minded people, who comment on posts or during live-videos of their favourite star. Thus, fans can increase their knowledge using fan-fan interaction. $^{5}$

This cohesion can be fuelled by the social media stars, who skilfully use platform features such as hashtags, ${ }^{6}$ e.g. on Instagram or Twitter. Some stars create their own keywords to mark their personal content. These individual hashtags are later not only used by the star himself or herself but also among fans, thus, making it possible for others to easily find the related content. Fitness stars on Instagram, for instance, use specific hashtags for their fitness programmes, which subsequently unites all participants following their fitness schedule (and posting tagged content). As every member has to complete the same workouts, the experience of others is helpful and supportive. The more like-minded athletes become available, the more utility every single person can derive from the network. Hence, these hashtags connect all fans, leading to strong direct network effects.

5 For star-fan interaction see chapter 0.

6 Hashtags are keywords or catchwords used in social media, which are created by placing the sign "\#" directly in front of it. These words are intended to convey the key message of the content and simplify the possibility to find the respective content (and similar posts). 
Moreover, in social media the positive direct network effects are not only one-dimensional but may be two-dimensional: online and offline. As described above, direct network effects arise on social media platforms and online communities evolve. The bigger the network, the better the chances of finding interesting conversation partners. However, in addition, fans who meet online may transfer the connection to offline relationships (similar to online-dating). Continuing the fitness example, participants of a workout programme first connect online via the star's pages and then might be able to find a partner to actually practise with offline. The chances to find a suitable partner (of the same fitness level, for example) in a geographically limited area are much higher, if one follows the biggest and most famous stars.

Summing up, it can be said that the effects assumed by Adler can also be found in social media markets and the nature of the market even increases network effects. The digital environment simplifies communication, decreases the cost to reach a huge audience and network effects multiply more rapidly than in offline markets.

\subsection{Summary: The Role of the Old Windows}

Altogether, the idea that superstardom in social media represents a completely new phenomenon and "traditional" superstar theories lose their explanatory power in this new media environment must be rejected. The role of talent is very similar to traditional markets - including similarities between sports and e-sports. Furthermore, the typical market concentration effects (see Figure 1), which are constitutional for the traditional economic theory of superstars, are also present in social media markets. Moreover, both MacDonald-style effects and Adler-style effects - both describing the dynamics of superstar markets - belong to the fundamental mechanisms of social media stardom. Initial empirical evidence supports this conceptual and theoretical assessment (Budzinski \& Gaenssle 2018). The distinction between self-made superstars and manufactured celebrities does not appear to be helpful in social media markets (as it is now) - and may also be questioned for traditional markets.

So, is there nothing new under the sun? First, it needs to be noted that the effects and mechanisms described by the traditional theory partly come in a new disguise in 
social media, which, for instance, for Adler-style effects implies an increasing relevance because of stronger and more radical mechanisms. Second, a continuing relevance of traditional theoretical concepts of superstardom do not necessarily exclude the emergence of additional new factors. The following chapter discusses such new factors as they are brought up in the literature and in public discussion. We shed light on whether they actually represent novel factors that are exclusive to social media.

\section{New Factors in Social Media}

\subsection{User Generated Content, Prosumption, and Platform Economics}

In the existing literature on social media and related stars, in particular two phenomena with a view to economics, are discussed as new features: user-generated content and prosumption (inter alia, Kaplan \& Haenlein 2010, Ritzer \& Jurgenson 2010, Dennhardt 2014, Fuchs 2014, Morreale 2014, Detel 2017; sometimes also produsage, e.g. Bruns 2008).

Even though the majority of the literature discussing these ostensibly new features is not from within economics, it draws important conclusions for economics, i.e. fundamental concepts of microeconomics are declared to be outdated and in need of being replaced by these two new concepts. In this section, we take a critical look on (i) what these new concepts actually contain and (ii) whether they are suitable to replace standard economic thinking.

The term user-generated content (UGC) "is usually applied to describe the various forms of media content that are publicly available and created by end-users" (Kaplan and Haenlein 2010: 61). It is often defined by three characteristics (inter alia, OECD 2007, Kaplan \& Haenlein 2010):

(1) UGC is any content published on a website or on a social network site accessible to the public or at least to a selected group of people. This condition excludes, for instance, content exchanged via emails or messengers.

(2) The content needs to entail a creative effort, excluding mere replications of already existing content. 
(3) UGC must have been created outside of professional routines and practices, excluding all content that has been created with a commercial market context in mind.

For our purposes, the third precondition is particularly relevant. Given the multibillion-dollar nature of the business, content provided by social media stars is clearly not created outside of professional entertainment business and commercial market context. In contrast, it represents a highly commercial endeavour, both from the sides of the content providers and from the side of the social media platforms. Consequently, the term UGC - following this definition - does not apply to social media stars.

In a broader definition, UGC could simply refer to content provided by users of a given platform, irrespective of commercial purpose or character. However, all content on social media platforms is user-generated since it is impossible to upload content without being a platform user. Consequently, we can then simplify and just use the term content.

However, the quote by Kaplan and Haenlein (2010) additionally refers to another interesting economic dimension in the discussion: they refer to content created by end-users, i.e. consumers. The idea that users are simultaneously producers and consumers of content has led to the introduction of the term "prosumption, a term that describes the implosion of production and consumption that characterises Web 2.0" (Morreale 2014: 114). The original literature on prosumption focuses on the increasing division of labour in the course of the so-called Industrial Revolution, which allegedly "separated production and consumption, but [...] also contends that even at the height of the Industrial Revolution production and consumption were never fully distinct (producers consumed raw materials; consumers produced their meals) [...]. This false binary is rejected [...]" (Ritzer \& Jurgenson 2010: 17). The "contemporary society is moving away from the aberrant separation of production and consumption and towards a 'third wave' that, in part, signals their reintegration in 'the rise of the prosumer' (Toffler, 1980: 265) "(Ritzer \& Jurgenson 2010: 17). Often in combination with UGC, the concept of prosumption enjoys considerable popularity among authors discussing social media content and its economic dimensions, including the 
phenomenon of social media stars (inter alia, Dennhardt 2014, Fuchs 2014, Morreale 2014, Grabs \& Bannour 2016).

However, from an economics perspective, there seems to be a misunderstanding. The terms producer and consumer describe the economic roles of production and consumption and are not attached to single persons who either do one or the other all of their time or in their whole life. Every individual acting as a producer is and has always been acting as a consumer as well - in a different and usually separable economic role. Of course, a food producer (i.e. a farmer) or a supermarket owner will also consume food. Still, the two roles are distinct: either he or she acts in a specific situation as a producer (i.e. producing, retailing or selling food) or as a consumer (i.e. consuming food or buying it for consumption). Both actions are usually separated by time and, even if not, can always be separated analytically. This logic also applies to content providers in social media: the same person either acts in a specific situation as a producer (i.e. producing a video or a picture and/or uploading it to YouTube, Instagram and co.) or as a consumer (i.e. watching a social media video or picture). Thus, there is neither an "implosion" of production and consumption, ${ }^{7}$ nor are these standard economic concepts becoming obsolete in the modern internet economy. ${ }^{8}$ Both approaches, prosumption and UGC, seem to be intuitively fitting due to the personal nature of some social media content and the possibility of noncommercial provision of those. Private or even intimate information can be published by any platform member. Still, in the economic sense even non-professional, noncommercial content providers are producers in the moment of provision/posting (see Figure 2). So, it actually does not even matter, whether the production of contents is commercial (as in the case of social media stars) or not (as in the widespread sharing of family or pet videos). In summary, talking about UGC and prosumption does not add any insight to the analysis of social media stars and is inadequate from an

7 Ritzer and Jurgenson (2010) depart from standard economic understanding, when they claim that (i) "producers consumed raw materials" and (ii) "consumers produced their meals". In (i) producers are customers exerting a demand for upstream goods but not consumers (= end-users) and in (ii) someone cooking his or her own meal indeed acts as (non-commercial) producer while cooking and as a consumer while eating. Even if he or she already eats while cooking, the two actions can analytically be separated, which is useful because of the differing economic implications.

8 A different question is whether there is a new importance or a new level of interaction between stars and their audience in social media (sometimes confusingly labelled co-creation). We discuss this question in section 3.6. 
economic point of view. Like in the more traditional entertainment world, there are stars providing entertainment content (producers) and there are recipients consuming this content (consumers).

A related but different notion would be concepts of joint production, i.e. online services and users co-produce a good with the user injecting its personalised data as an input to the production process. However, producers employing available information about their customers to shape goods according to the so-perceived preferences represents an element of any competitive supply of goods. While the availability of information from and about customers considerably increases in the online world, it remains an endeavour of suppliers seeking to match customer preferences rather than any type of co-production. While data-driven business models - which are discussed more in detail in section 3.2 - indeed significantly shape the commercial environment of social media stars, they do not require any productive or creative activity from users, just standard consumption behaviour. Similarly, communicative star-fan interaction may influence online stardom (see section 3.5) but merely provides additional information channels about consumer preferences rather than associating a producer role with video (YouTube) or picture (Instagram) watching and commenting.

The business model of the currently prominent social media platforms, however, does resemble what modern economics describe as platforms (inter alia; Rochet \& Tirole 2003, 2006, Armstrong 2006, Anderson \& Gabszewicz 2006, Haucap \& Stühmeier 2016, Budzinski \& Kuchinke 2019). Social media platforms as suppliers serve three different customer groups: (i) content providers (commercially and noncommercially) demanding space for and access to their contents, (ii) content users consuming these contents, and (iii) advertisers demanding the attention of content users for the advertised goods. ${ }^{9}$ Through targeted advertising, the platform places the ads in a way as to maximise advertising revenues. On platforms with ad share policies, like YouTube and Twitch, commercial content providers receive a share of the advertising revenues created by ads placed/shown in the context of their content

9 These platforms can be characterised as artificial platforms. A business model based on subscription fees would also be possible, but is not chosen, presumably to attract users and initiate network effects. 
from the platforms (marked as dotted arrow in Figure 2). Some social media stars also directly place advertising in their contents (product placement) or cooperate with companies and are directly paid for this cooperation. This is the actual influencer part of social media stars, which can predominantly be found on platforms like Instagram or Twitter, where stars are not integrated into the platform-immanent advertising system. Next to direct network effects à la Adler (see section 2.5), this business model manages indirect network externalities (INE) in a commercial way (see Figure 2). These INE are economies of size on the demand side and describe that an increase in the quantity of content providers increases the utility for content consumers and vice versa. Similarly, an increase in the number of content consumers (overall or from specific target groups) increases the utility of advertisers. However, while these are all positive INE, it is rather unclear whether an increase in advertising will increase the utility or the disutility of content consumers (e.g. increasing their advertising avoidance costs) and, thus, whether this specific INE may be negative.

Figure 2: Multisided Social Media Platform

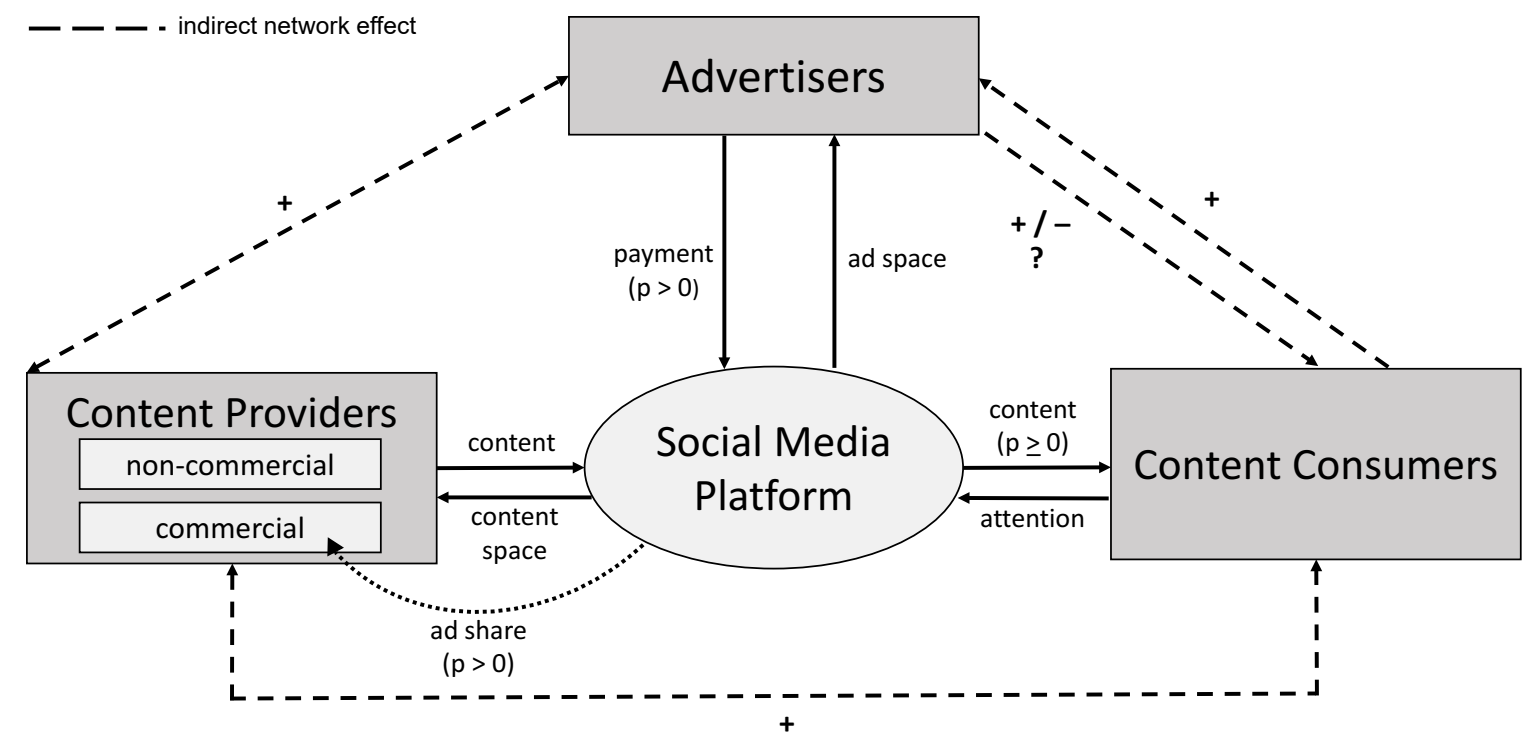

Modified and enhanced from Dewenter \& Rösch (2015)

The implications of platform economics relate particularly to the market structure of the platform market. Due to the INE, this market will be concentrated on a few big platforms with considerable market positions. In tendency, this weakens the market 
power of superstars (as described in the traditional theory, see section 2.3) compared to more fragmented media industries that traditional stars often used to face.

\subsection{Algorithm Management}

The increase of available information (so-called big data) drives the importance of algorithms. ${ }^{10}$ Content-specific platforms like YouTube or Instagram use algorithms to collect and analyse consumer data. This personalised data ${ }^{11}$ is used for, firstly, targeted advertising, which means that consumers "pay" with the provision of their personal information (see platform economics in section 3.1) to subsequently receive individually customised advertising. Advertisers are, thus, willing to pay higher prices for more effective advertising to reach their specific target group.

Secondly, the provided data is used for tailor-made recommendations of contents as well as search results within the platform. Based upon the consumers' individual historic behaviour and preferences, so-called personalised recommender systems and personalised search engines create an individual compilation of contents (inter alia, Belleflamme \& Peitz 2018, Budzinski \& Lindstädt-Dreusicke 2018). Although, the details of the algorithms generally remain business secrets of the platforms and are changed/adjusted frequently (Budzinski \& Kuchinke 2019), different aspects are known to have an influence on content recommendation: inter alia, the content "age" since upload, the total number of views and likes of the content in question as well as the audience size of the uploader (Borghol et al. 2012). From an economic point of view, the individualised selection of content recommendations and search rankings is thus based on both stated preferences (likes, comments, tags or posts) and revealed preferences (actual viewing history, consumption time, search commands, etc.) by the users (Budzinski \& Kuchinke 2019). Thus, it delivers the user who types in a search term with an individualised results ranking that follows his or her

10 Different aspects on algorithms can be found in scientific literature. On the demand side, digital personal assistants (Budzinski et al. 2018), algorithmic consumers (Gal \& Elkin-Koren 2017) and bots (software robots, which are designed to exhibit human-like behaviour) (Ferrara 2015, Ferrara et al. 2016) can be named. On the supply side, price-setting algorithms raised concerns of novel competition problems and collusive behaviour among competitors (Ezrachi \& Stucke 2015, 2016a, 2016b, 2017, Mehra 2015, Pasquale 2016, Oxera 2017, Woodcock 2017, Schwalbe 2018).

11 On data-based services, personalised data and privacy also see: Acquisti \& Varian 2005, Acquisti et al. 2016, Brown 2016, Budzinski \& Kuchinke 2019, Budzinski \& Stöhr 2018. 
preferences so that the probability increases that the user quickly finds what he or she is searching for. Furthermore, each user receives - unrequested - an individualised ranking of content recommendations again increasing the probability that the recommended content is interesting for the user. Both algorithm-based services enhance the probability that users consume more contents (thus stay longer within the platform) and visit the platform more frequently since these services - together with low sampling costs - reduce information uncertainty of consumers, i.e. represent (imperfect) information about content quality in the eyes of the users.

Every social media platform has specific and individualised recommendation sites and overview pages and they distinguish (data-based) online media from virtually all traditional media. Furthermore, these algorithm-based services influence superstar mechanisms in different ways. In the multisided market of social media, different players experience different incentives how to deal with or use the underlying algorithm. In the following, (i) the content providers and (ii) the operator of the algorithm, the platform itself, are analysed with respect to the superstar phenomenon.

\section{(i) Content Provider Perspective}

Content providers need specific knowledge of the respective platform and its algorithm to successfully place posts and manage contents. Like with other data-based services, users' consumption choices heavily depend on the content that is presented prominently (i) in the search results and (ii) in recommendations individualised-displayed for these users. Many consumers tend to choose among the top-listed search results in prominent position (Ghose \& Yang 2009) and follow top-listed recommendations. While the ranking of search results and recommendations is considerably based upon individual personalised data (stated and revealed preferences like the individual consumption history, etc.), even the potentially matching content would be too much to adequately reduce the information overflow problem of the consumer. Thus, additional criteria for algorithmic selection and ranking seek to further enhance the probability of extended consumption. Understanding or anticipating the working properties of the algorithmic selection means for content providers that the probability of being prominently displayed in search and recommendation results 
may be strategically increased - something which is imminently important in order to reach audience and avoid to be disappearing in information overflow (i.e. being downlisted to the second, third, etc. pages of search results and recommendation items).

Being prominently listed is paramount for success in the social media world as even the best content will not find any relevant audience without being pre-selected by the algorithm-based search and recommendation services. With the help of advanced linking-logic, as e.g. the usage of keywords, cross-referencing and networking, ${ }^{12}$ single posts can be pushed and spread. The art of adapting contents to the specific algorithms can be refined through experience. Sophisticated market players, like social media stars or their agencies and multichannel networks (see section 3.3), continuously learn and improve their algorithm management skills and built up competences. Experienced incumbents can, thus, iteratively improve their system and outdo amateurs so that consumers easily find their content highly-placed in the respective recommendations (Budzinski \& Gaenssle 2018). These learning effects lead to advantages for professionals and incumbents, which can increase barriers to entry for newcomers.

The specific selection of contents by the platform's algorithm-based search and recommendation services pushes certain contents and increases their reach and popularity. So within the massive content provision some particular posts are chosen for recommendations, automated playbacks, explore sites, etc. and, thus, pushed and supported to get even more attention. If an uploader is able to play the algorithm and successfully manages the recommendation system, it will increase the posts' reach and fuel snowball effects.

Eventually, algorithm management matters as a core factor of social media success. Due to the frequent evolution of the algorithms by the platforms, algorithm management is always imperfect and remains a permanent challenge for social media stars.

12 Cross-referencing and networking means linking other social media stars in the content, generating joint content or being featured on other social media accounts. 


\section{(ii) Platform Perspective}

Platforms like YouTube or Instagram are sometimes perceived as offering a "neutral" space for content providers to fight for the attention of the audience on a level playing field. However, profit-maximising platforms experience incentives to engage in strategic algorithm policy and to push and promote certain content and suggest it to respective target groups, in particular if they enjoy powerful or dominant market positions. With its algorithm-based recommendation service, the platform decreases search costs and information overload for consumers. The goal of this aggregation service is to simplify consumption and, in doing so, increase the total consumption on the platform. Managing its algorithm (which is the platform's property), the platform maximises its turnover and profits (Budzinski \& Lindstädt-Dreusicke 2018).

Obviously, the platform experiences incentives to manage its algorithm in a way that consumers get what they want, i.e. content according to their preferences. This implies both the use of personalised user data in order to approximate the preferences of the user and the promotion of successful contents (with respect to similar consumers/target groups) that have a high likelihood of being liked. While the star-making effects of these two aspects are well-explored in the preceding sections, another incentive, however, points to an even more sophisticated selection process. Due to the information overflow character of available content and the consequent dependence of users on the algorithmic pre-selection of the platforms, the latter gain scope for injecting profit-interests into their algorithm management which departs from strictly looking at consumers' preferences: scope for a recommendation and search bias exists, especially in the case of market power by the platforms.

Social media platforms experience incentives that involve creating their own stars (who may be easier to control) over further supporting the most successful stars with a lot of bargaining power (Franck \& Nüesch 2007). Due to their extraordinary talent, superstars enjoy a certain degree of bargaining power (Rosen 1985, Borghans \& Groot 1998), which allows them to acquire a considerable share of the rents that may be earned with their contents. Therefore, the platforms have an incentive to push content of hand-picked platform immanent stars, rather than deal with major 
stars that have more bargaining power and might not easily accept restrictive contracts or conditions. In this case, they may be able to acquire a larger share of the rents for the platform itself, at the expense of the content provider. In fact, platforms are indeed looking for potential newcomers, who are starving for attention and success and are willing to invest in their social media career. The creator academy by YouTube is a good example for this phenomenon. YouTube operates this channel to educate content providers and share information from "YouTube experts" (YouTube 2018b). Furthermore, platform-connected agencies are involved in creating new stars (see chapter 0 ), like, in the case of YouTube, so-called multichannel networks. They teach newcomers how to become stars, adding those to the network.

By cooperating with those agencies, the platform creates and supports in-house stars and, thus, intensifies the competition among content providers. This strategically spreads the bargaining power among them and increases the economic dependence of content providers on the platform. Platforms may support this profit-maximising strategy by using their scope for recommendation biases and systematically favour their own, more dependent stars over more independent ones. Thus, platform algorithm management has incentives to balance preference-conformal selection to please users with platform-partners-privileges selection to maximise profits. Hence, social media stars may not be in the traditional sense "media-made", but, some may be "platform-made".

\subsection{Changing Roles of Gatekeepers?}

The role of gatekeepers, i.e. those who control access to the audience in media markets, has always been a crucial issue. In traditional media markets, the access to the audience is often limited by editing processes of media companies. The latter and their editorial offices used to decide which contents are broadcasted, for instance in traditional TV, or printed, for instance in magazines, and, thus, played an important role in the generation of stars and for their further careers. Many authors from various disciplines assume, however, that the social media world, by contrast, is characterised by a large-scale shift towards integration and participation of the masses (inter alia, Benkler 2006, Jenkins 2006, Bruns 2008, 2011, Bruns \& Highfield 2012, Shirky 2008, 2011, Castells 2009, Jenkins et al. 2012). It is argued that "traditional 
media have lost their institutional monopoly over the mass production and distribution of news, entertainment, and opinions" (Blank 2013: 591). Every member of a social media platform is principally able to publish content, giving the individual power to spread information among all members and making traditional editors, intermediary mediators or gatekeepers, who select and prioritise, obsolete in this process.

In the literature, the implications are either hailed as a democratisation of content or "democratainment" (Hartley 1999, Bruns 2008, 2011, Bruns \& Highfield 2012, Detel 2017) or demonised as loss of content quality (Singer 2010), persuasive messages (Chang et al. 2015) or "cultural decay" (Molthagen-Schnörin 2017).

The former reasoning shares a sceptical view of the power of (elitist) editorial offices in traditional media, whereas the latter one emphasises their quality-preserving expertise. In the following, we argue that none of these radical positions fit with the economic reality in social media markets and that the role of gatekeepers for stardom development has evolved rather than become obsolete.

Even though there is a large content production and a lot of information available, there is only so much information the consumers are able to process. ${ }^{13}$ The consumption capacities per unit of time are limited (scarcity of attention) (Simon 1971, Falkinger 2008). Attention on the consumer side is finite (as it has always been) and the provision of too much content leads to information overload situations. Therefore, the need for selection and prioritisation remains relevant: the average consumer has neither the time nor the resources to hand-pick individually interesting information out of all existing online content. This is why platforms use algorithmic recommender systems to pre-select content (also quality-wise) potentially fitting individual consumer's preferences (see chapter 0), thereby, dealing with the bottleneck of scarce attention. Consequently, platforms act as gatekeepers and are often described as "aggregators" of content (Detel 2017). Social media platforms are thus able to chan-

13 On economics of attention markets also see: Evans (2013, 2017), Boik et al. (2017); and building on Becker (1965) see: Goolsbee \& Klenow (2006), Brynjolfsson \& Oh (2012). 
nel (i.e. influence or even manipulate) the streams of attention, (at least partly) replacing former mediators and gatekeepers in the content production and star creation process - in particular if they enjoy market power. ${ }^{14}$

Another potential gatekeeper in the social media market are managing agencies, for example, so-called multichannel networks (MCN) in the case of YouTube. These agencies represent stars and engage in supporting services (e.g. support in production, distribution and marketing; cross promotion with other stars of the network; digital rights management; organisation of live events and merchandise; audience building). Figure 3 visualises an extract of the multisided social media market (as pictured in Figure 2, chapter 3.1) and adds the role of agencies within the system.

Figure 3: Role of Agencies in the Multisided Social Media Market

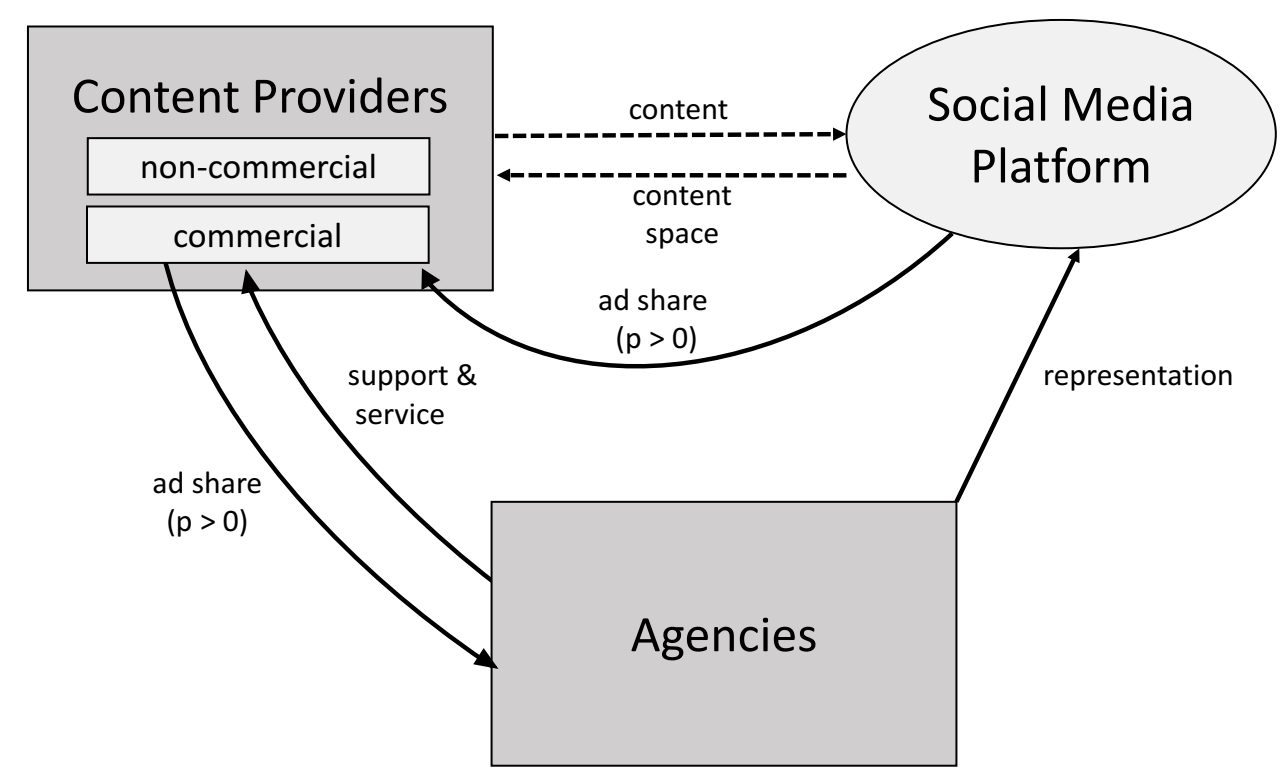

Modified and enhanced from Roß \& Weghake (2015)

14 For instance, Google increased the requirements for monetarisation of YouTube accounts: "Once a channel reaches 4,000 watch hours in the previous 12 months and 1,000 subscribers it will be reviewed to join the program." (Google 2018). 
These agencies act as "silent power" behind the stars. Numerous top YouTube stars are under contract with large multichannel networks - without awareness of the audience. ${ }^{15}$ It can be argued that with the rising power of agencies it becomes a necessity to be under contract with one of the major agencies in order to be successful, connected, and visible. The market experience in algorithm management, the integration into a substantial star network and the provision of equipment and knowledge can make a big difference for potential stars and newcomers.

A closer view of the ownership structures reveals that the most relevant agencies are owned by big media companies that are well-known from traditional media markets and comprehensively integrated in the global media market (see Table 2). Most top MCNs belong to media conglomerates, which operate in various media fields (print, audio and audio-visual media). Consequently, upcoming and aspiring stars still face gatekeepers in order to gain access to a relevant audience. The players might have new names but the functionality, influence and ownership structures resemble the old model. While social media markets are still developing with various changes and fluctuation, it is already anticipatable that the role of gatekeepers is re-establishing itself.

15 In 2015, 70-80 percent of the top 100 channels in Germany cooperated with MCNs (Roß \& Weghake 2015). Unfortunately, newer information is barely available. Socialblade, for instance, stopped providing information on MCNs since they now engage in YouTube consulting themselves. 
Table 2: Top 15 Multichannel Networks

\begin{tabular}{|l|l|l|l|}
\hline MCN & Parent Company & Members & Subscriber \\
\hline BroadbandTV & $\begin{array}{l}\text { RTL Group, } \\
\text { Bertelsmann }\end{array}$ & 238,649 & $78,457,936$ \\
\hline vevo & Universal/Sony & 12,033 & $34,798,588$ \\
\hline AIR & AWARDS MEDIA GROUP & 37,477 & $25,419,132$ \\
\hline Fullscreen Network & AT\&T, WarnerMedia & 68,250 & $24,428,549$ \\
\hline Yoola & - & 43,579 & $22,696,094$ \\
\hline Studio71 & ProSiebenSat.1 & 13,174 & $13,900,550$ \\
\hline ScaleLab & - & 23,306 & $11,609,881$ \\
\hline $\begin{array}{l}\text { Maker Studios/ } \\
\text { Disney Digital Network }\end{array}$ & Disney & 9,419 & $10,270,788$ \\
\hline Yeah1 Network & Yeah1 Group & 4,602 & $10,124,935$ \\
\hline Freedom! & * & 103,345 & $9,221,166$ \\
\hline Believe & $*$ & 71,835 & $8,817,765$ \\
\hline ONErpm & - & 21,874 & $8,509,317$ \\
\hline Union for Gamers & Amazon & 10,604 & $8,201,850$ \\
\hline theorchardmusic & Sony Music & 125,951 & $7,862,389$ \\
\hline Machinima & AT\&T, WarnerMedia & 8,501 & $7,139,399$ \\
\hline
\end{tabular}

$22^{\text {nd }}$ November $2017,{ }^{16}$ sorted by Subscriptions

Socialblade (2017)

\subsection{Upload Behaviour and Specific Investment}

A relevant first step towards social media stardom is the content creation and provision on social media platforms. It evidently requires a minimum activity to gain popularity and followers, which means that content uploads positively influence success (as in growing numbers of views and subscribers). Yet, providing too much information can reverse the effect and may have negative effects on further consumption. Budzinski and Gaenssle (2018) find empirical evidence with respect to YouTube that increasing uploads per time unit at first have positive influence on views and subscribers (low level/few uploads). However, this effects flips with growing quantity of

16 Last available data collection of Socialblade, retrieved via Wayback Machine.

* Parent company is unknown

- Company is independent 
uploads (high level/many uploads), resulting in a non-linear U-shape relation between uploads and success. See short-term (S) and long-term (L) effects in Figure 4.

\section{Figure 4: U-shape Relationship: Success and Upload}
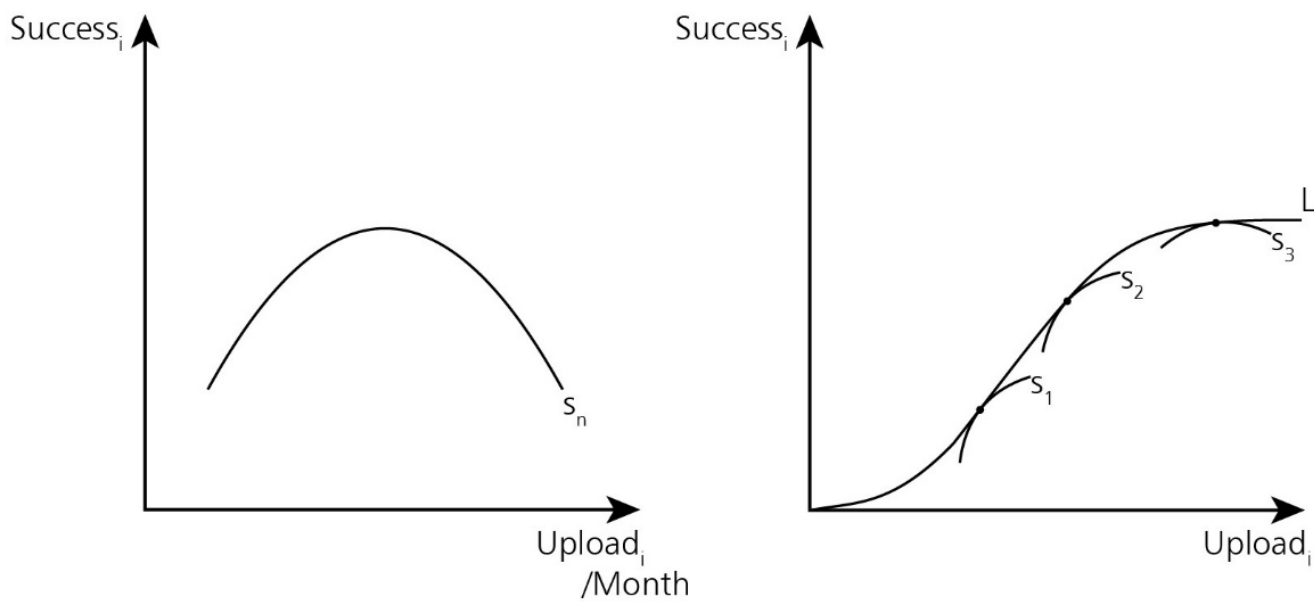

Budzinski \& Gaenssle (2018)

This effect can be explained by (i) limited consumption capacities and/or (ii) limited production capacities:

(i) Information overload on the consumer side (see chapters 3.2 and 3.3) can lead to attention withdrawal. Content providers need to offer sufficient content for information-hungry "heavy" users, while not providing too much information for attention-scarce ones. Too much content can get tiring and overstraining for average consumers, since it is either not possible to follow all of "your" star's news or the mass of information and notifications become annoying and tedious. This strongly depends on the cost of consumption; the time spent absorbing the respective information, which widely varies between different content categories (inter-category: e.g. video versus picture) and its complexity/length/context (intra-category: e.g. video clip vs. tutorial video, snapshot vs. artwork).

(ii) The quality of the content is also crucial on provider side. A high frequency of uploads increases the pressure on creativity to constantly produce new ideas. Production time and technical standards must be kept to meet consumers' expectation and keep the quality at a certain level. Hence, it is 
possible that the quality of the content decreases with high output; exhausting the producer's capacities and driving consumers away.

Eventually, in order to succeed in the long run, content providers need to constantly upload a certain amount of content to attract attention and build an audience, while at the same time not overstraining them by (low-quality) volume. It is a narrow line between feeding interesting and entertaining information and spamming low-quality quantity. The optimal upload frequency varies with the type of content. For instance, average consumption efforts are considerably lower for picture-platforms (like Instagram) than for video-platforms (like YouTube), which should influence optimal frequency as should the lower production costs of content in the former. To our best knowledge, however, no comparative empirical research exists here so far.

Content providers and future social media stars need to heavily invest in audience building and maintenance by constantly generating and uploading new content. It is inevitable to create a solid content base in the beginning to convince potential consumers of the account's quality. If the available content meets their preferences, they subscribe to the channel/account to receive future contents (experience good characteristics). A newcomer needs to draw attention and reach a critical mass to kick-start reinforcing effects à la Adler (see chapter 2.5). This requires specific investments in the beginning with little reward and audience feedback. Social media stars need to put hard work and comprehensive personal input into the creation of their stardom. The step from moderately successful content provider (medium star) to becoming an actual superstar requires perseverance and commitment. Like with all types of stars, the belief in yourself, your skills and capabilities must be strong enough to persevere in the face of negative feedback, setbacks, ignorance and doubts. The notion of hobby-style content uploaders, who accidentally tumble into stardom, does not reflect the typical contemporary reality of social media stars or at least not of the top end superstars (and the few exceptions usually date back to the earlier days of the platforms when the overflow of information was much more limited). Social media newcomers need high frustration tolerance and robustness to keep up quality uploads and succeed in the long run. This persistent and specific investment in audience building can represent a considerable market entry barrier for newcomers. 
The relevance of both factors, specific investments in long-term audience building and strategic upload behaviour (a balancing act between too few and too high upload frequencies), essentially contributes to the success of social media stars. While this may resemble phenomena in traditional media - a too frequent appearance of an individual actor on TV may also overstrain/annoy the audience - social media stars can more directly manage their upload behaviour and media presence. Exaggeratedly, upload management is "feeding" tailor-made contents in right amounts to the respective (self-created) audience. This audience creation and long-term maintenance crucially differentiates social media stars from stars of traditional channels. Thus, here is another factor where the influence of a star on his or her success is of a different quality than in the traditional world.

\subsection{Authenticity and Accessibility: Ordinary People as Stars and Fan-Star Interaction} In the existing literature on social media stars, authenticity is often emphasised as an important success factor of this type of star (inter alia, Döring 2014, Marwick 2015, Audrezet et al. 2018, Burgess \& Green 2018). It remains unclear, though, whether authenticity is meant to be a superstar-making factor within social media content providers, i.e. that a more authentic social media star is more successful than a less authentic one, or whether it is meant to explain the attractiveness and appeal of social media stars vis-à-vis stars from traditional media. For instance, a German study of YouTube stars by Google shows that, in contrast to TV, film, and music stars, YouTube stars are specifically valued among teenagers for their credibility, authenticity and closeness/tangibility (Google 2016). ${ }^{17}$ This empirical result points more to authenticity being a success factor for social media stars in competition with traditional stars - and within a younger audience! We are not aware of any research attempting to measure the influence of authenticity on the competition among social media stars.

17 In the main part of the study, 700 German teenagers between 13 and 19 answered an online questionnaire with regard to different characteristics as, inter alia, role model function, authenticity and credibility. 
The narrative from the literature concerning why social media stars are perceived to be authentic, real and accessible consists of two fundamental aspects: (i) their "commonness" or "ordinariness" and (ii) the enhanced fan-star interaction.

Starting with the first aspect, social media stars may firstly be seen as "ordinary" people who upload content on their (ostensibly private) accounts. Consumers may experience the star as "one of us". The "shift from the elite to the ordinary" (Turner 2006: 154), from distant stars to so-called "DIY celebrities" (Turner 2006, Burgess \& Green 2018), may increase possible identification with the star. Sometimes social media stars actively engage in self-presentation by uploading (semi-)private content. This way they create a strategic intimacy to please their audience (Marwick 2015). Secondly, the ostensibly direct contact to fans without intermediate gatekeepers (like interviewers, reporters or publishers from traditional media) may decrease possible interferences and/or biases of retelling and editing (Detel 2017: 320), allowing the stars to share their pure, individual, and unfiltered view. An unbiased personal perspective of their star seems to be of great importance to many adolescent fans (Google 2016) and may enhance the impression of authenticity and closeness. Thirdly, a certain effect of satiation of the traditional (and superficial) glamour star world may play a role. Compared to some high-gloss marketing content of stars in traditional media, social media stars may seem to be closer to real life (of an average person in industrialised countries), which is strategically fuelled by behind the scenes pictures, interaction with the camera and/or self-presentation in allegedly private or vulnerable situations, e.g. without makeup.

However, the reasoning in this paper has clearly demonstrated that top end social media superstars act in a highly professional and commercial environment and do not present "ordinary people" accidentally being a "one-of-us"-star. ${ }^{18}$ Instead, they are part of a profit-maximising entertainment industry including commercial platforms, commercial agencies (e.g. multichannel networks), professional consultants, and the online advertising industry. Therefore, the issue of authenticity needs to be

18 While the narrative of "ordinary people stars" may have some credibility for the early days of social media, the professionalisation of social media entertainment is, by now, a well-established development (inter alia, Kim 2012, Döring 2014). 
put into perspective: most of the top stars have teams behind them to support different stages of commercial content creation - from content conception over production to distribution. Strategic staging and content adjustments to audience preferences are as prevalent on YouTube \& Co as it is in traditional media (perhaps even more so due to algorithmic selection and availability of personalised data). Moreover, instead of just being "unfiltered", stars need to adapt their content according to platform standards, regulations, and policies to ensure that it is not deleted. ${ }^{19}$ Eventually, next to the big commercial platforms, the "old" media giants gain influence in social media entertainment and stardom (see sections 3.2 and 3.3).

So, what may be a success factor here is much more perceived authenticity than authenticity itself: as long as stars are perceived as being authentic, it does not matter whether they really are authentic or not. The perception of authenticity, however, is subjective and depends on the perceiving individual. Whether social media stars are perceived as being authentic or not may crucially depend on the age of the perceivers: while a teenager may view gaming, unboxing or make-up stars as being very authentic, older people may come to the opposite perception. Identification - a relevant driving-force of perceived authenticity - considerably correlates with factors like same age, same interests, same worldviews, etc. When, as in the studies we are aware of (like Google 2016), people between 13 and 19 assess social media stars as more authentic than traditional stars, this may also be rooted in a generation effect. Every generation favours its new stars and - most probably - perceives them as being more authentic than the stars of their parents' generation. Incidentally, the normal generation change of stars in the 2010 s coincides with the switch of the main entertainment media technology from TV to social media (Budzinski \& Lindstädt-Dreusicke 2018) in the younger generation.

The second dimension of authenticity and accessibility relates to an enhanced fanstar interaction. The possibility to directly and immediately comment on any of the star's content (via posts, likes, etc.) together with the possibility of the star to directly react to comments (via answering fans' comments in posts, videos or livestreams but

19 A popular example is the YouTuber Pewdiepie (Felix Kjellberg) who posted anti-Semitic videos and caused YouTube and Disney to cut ties with him (Winkler et al. 2017). 
also via re-posting comments or contents from fans) may dissolve the traditional audience-star dichotomy, leading to a true dialog between fans and stars (Marwick 2015). In doing so, it enhances the accessibility and (perceived) authenticity of the star.

Now, of course, fan-star interaction is not per se novel. In the traditional media world, fans wrote emails and letters to their stars, asking for autographs and posing questions and comments. The main difference in the social media world is that digitisation and the internet have drastically reduced the costs of communication. Following fundamental economic logic, lower costs and accompanying prices increase demand, therefore, it is not surprising that lower costs of fan-star communication enhance fan-star interaction. Furthermore, the costs of geography have also been massively reduced by digitisation and the internet. As a consequence, the costs of "bundling" one's own fan community have decreased in online entertainment and a social media star may reach its global fan base at significantly lower costs.

While the phenomenon is not new per se, its increasing quantity may come with a new quality. The ubiquitous availability of interaction options may turn fan-star interaction into a success factor since a social media star is in a better position to differentiate himself or herself from other social media stars by means of a more active fan management strategy. However, it should not be overlooked that the costs of fan management (time, manpower, etc.) still increase with the number of (communicating) fans despite the low communication costs. This implies, first, that social media stars need to select which posts to answer and what fan-made content to repost. Second, a personal handling of the fan-star interaction becomes more and more difficult with a growing fan community. While smaller and medium stars may still keep directly in touch with their fans - and, thus, fuel their perceived authenticity - the pressure on (top) superstars considerably increases with growing fame; forcing them to outsource certain tasks. Thus, they tend to rely on professional teams managing major parts of the fan-star communication. Whether this is still perceived as authentic, depends on the quality of the managing team.

Thus, the role of fan-star interaction as a success factor for social media stars can be considered as non-linear and dynamic. It may be an important factor for rising stars 
as long as they are on their (early) way towards superstardom. However, top stars with millions of subscribers will not be able to personally respond to "baskets of fan letters" daily. Eventually, the interaction intensity is likely to drop with a growing fan community. This is supported by empirical evidence on Instagram-stars, where the interaction strongly decreases for accounts with more than 1,000 followers (see Figure 5).

Figure 5: Interaction on Instagram according to Followers (2017) $)^{20}$

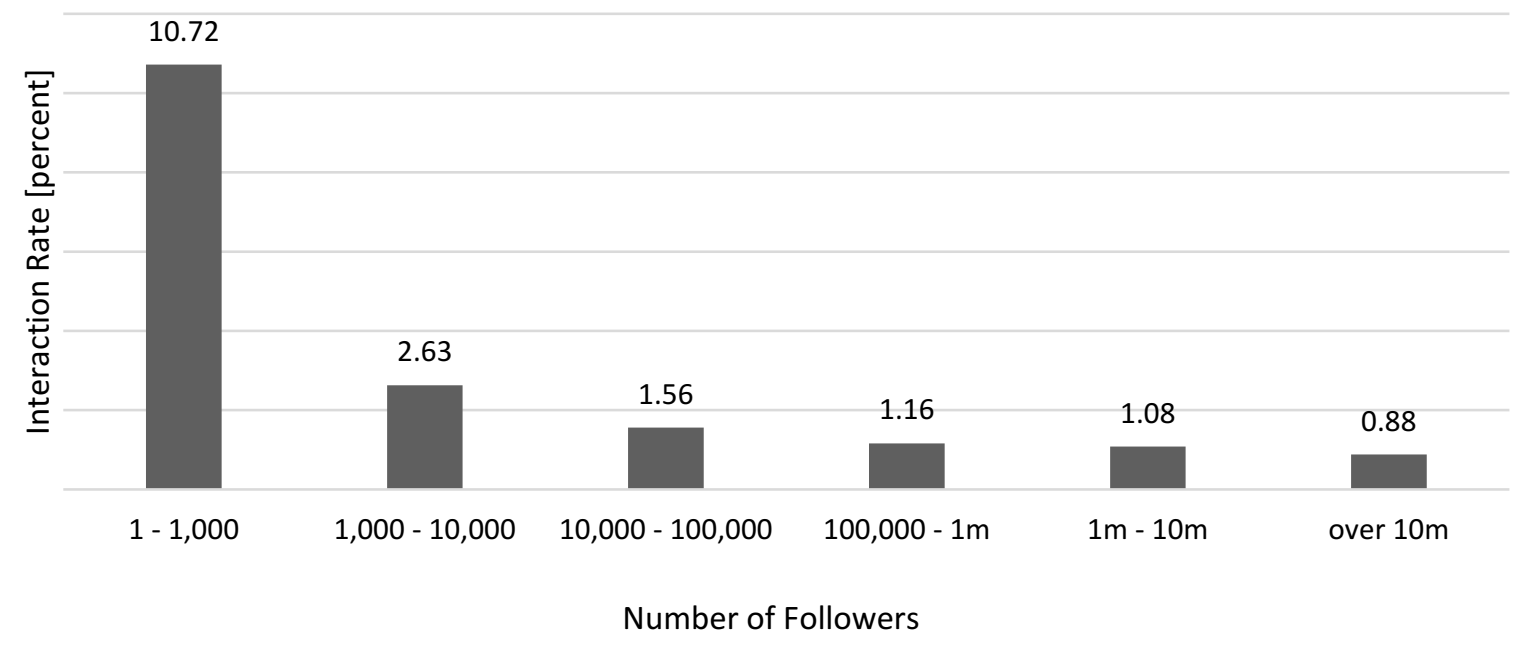

Pauriol (2017)

In summary, there is no convincing theory why authenticity should be a success factor between social media stars, rather than perceived authenticity being a slight difference compared to stars of tradition media. As the analysis shows, social media stars are far from being simply ordinary people (see also chapter 3.2 and 3.4) and fan-star interaction has increased, but loses impact with growing popularity. Furthermore, the literature often neglects that authenticity is not necessarily connected to positive or entertaining values. Being "authentic" automatically implies a positive connotation, but a truly criminal person may also be very authentic in what he or she is doing. Would that be positive or fuel star potential?

20 The study includes 740,000 Twitter, Facebook and Instagram profiles. Exact details on the respective Instagram accounts and the measurement of interaction are not mentioned in the source. 
Empirical research on the effects of perceived authenticity on social media stardom represents a research gap. The existing literature attempts to measure whether perceived authenticity is a factor in the appeal of social media stars for younger audiences (compared to traditional media stars). However, it fails to control for alternative explanations.

\section{Implications and Conclusion: The Role of the New Light}

In this paper, we review existing theories of the economics of superstars, originally developed for stars in traditional media, and discuss whether they are still applicable for stars in social media (chapter 2). Moreover, we analyse potentially new and additional factors for creating superstardom in social media that may be special to the nature of social media (chapter 3 ). Our overall result is that the economics of superstars remain applicable and relevant for social media stars, although the occurrence and shape of the effects contains social media specifics. Thus, one result is that not everything is new in the social media world compared to the traditional media world and many underlying mechanisms merely appear in a new light through the windows of old theory. In line with this assessment, we find that several (allegedly) new star factors in social media turn out to be either not new, not (properly) applicable or only partly different to factors concerning classic media stars. However, we also do find some elements that are not captured by traditional superstar theories and that are relevant for social media superstardom. Table 3 provides an overview of the success factors (traditional versus social media stardom) and the results of the analysis. 
Table 3: Success Factors - Social Media Stars vs. Traditional Stars

\begin{tabular}{|c|c|c|c|}
\hline $\begin{array}{c}\text { (I) } \\
\text { Not Applicable }\end{array}$ & $\begin{array}{c}\text { (II) } \\
\text { Unchanged }\end{array}$ & $\begin{array}{c}\text { (III) } \\
\text { Partly Different }\end{array}$ & $\begin{array}{c}\text { (IV) } \\
\text { Novel }\end{array}$ \\
\hline $\begin{array}{l}\text { Superstar vs. Ce- } \\
\text { lebrity } \\
\text { (distinction does } \\
\text { not fit) } \\
(2.2)\end{array}$ & $\begin{array}{l}\text { Talent } \\
(2.1)\end{array}$ & $\begin{array}{l}\text { Network effects } \\
\text { (stronger) } \\
(2.5)\end{array}$ & $\begin{array}{l}\text { Algorithm Manage- } \\
\text { ment } \\
(3.2)\end{array}$ \\
\hline \multirow[t]{3}{*}{$\begin{array}{l}\text { UCG, Prosumer, } \\
\text { Democratainment } \\
\text { (economically not } \\
\text { applicable) } \\
(3.1,3.3)\end{array}$} & $\begin{array}{l}\text { Market Concentration } \\
\text { (2.3) }\end{array}$ & $\begin{array}{l}\text { Role of Gatekeepers } \\
\text { (no complete omission } \\
\text { of gatekeepers, up- } \\
\text { coming new ones) } \\
\text { (3.3) }\end{array}$ & $\begin{array}{l}\text { Upload Strategies } \\
\text { (3.4) }\end{array}$ \\
\hline & $\begin{array}{l}\text { Risk-aversion, Infor- } \\
\text { mation Deficiencies } \\
(2.4)\end{array}$ & $\begin{array}{l}\text { Specific Investments } \\
\text { and Audience Building } \\
\text { (more self-reliant, } \\
\text { within the stars influ- } \\
\text { ence) } \\
(3.4)\end{array}$ & \\
\hline & $\begin{array}{l}\text { Perceived Authenticity: } \\
\text { "Only" Ordinary People } \\
\text { (3.5) }\end{array}$ & $\begin{array}{l}\text { Perceived Authenticity: } \\
\text { Accessibility and Star- } \\
\text { Fan Interaction } \\
\text { (lower cost, higher fre- } \\
\text { quency) } \\
\text { (3.5) }\end{array}$ & \\
\hline
\end{tabular}

(I) The distinction between self-made superstars and manufactured celebrities does not fit contemporary superstardom in the social media world. The "new" concept of user generated content (and thus all related approaches) are not applicable from an economic point of view, as the distinction between the economic roles (producer and consumer) still exists.

(II) With respect to the traditional economics of superstars, the role of talent, market concentration effects as well as dynamic effects of risk-aversion and information deficiencies (MacDonald-effects) are present in a comparable way in social media. We summarise supporting first empirical evidence where available. Regarding new star factors discussed in various strings of literature, we find several factors not to be properly convincing. The role of authenticity is particularly difficult, since it mingles different perspectives and is still under-researched. The analysis shows that social media stars are as far from being ordinary people as traditional stars. 
Still, the overall perceived authenticity and accessibility of stars tends to be higher and the cost of communication lower in social media markets. However, this merely differentiates social media stars from traditional stars, rather than serves as a new success factor to explain superstardom within social media, i.e. success in the competition among potential social media stars. Like every star, social media stars have to draw attention, build an audience and invest in their "star genesis", but are more independent in doing so. In the case of gatekeepers, the underlying mechanisms of gatekeeping display considerable changes; yet, there is no complete extinction of gatekeepers and the effects for superstardom remain very similar. Finally, network externalities (Adler-effects) are also very comparable to classic media markets, though the nature of the market strongly increases the effects.

(IV) We identify two success factors that are significantly different to the traditional media world: algorithm management and upload strategies. Both refer to behavioural scope for social media stars that did not exist in the traditional media world. Managing algorithmic search and recommendation systems and optimising upload frequencies is indispensable if potential stars want to stand out among the considerable bulk of contents on social media platforms and (i) reach the attention of the audience, (ii) build a growing audience for themselves, and (iii) maintain the growth of the audience into superstardom. This task is unique to social media and complements traditional superstar mechanisms which remain relevant. It is a task that requires skills and competences.

As such, the notion that everyone can easily become a star in the social media world is misleading. At first sight, it does appear to be easy to become famous on social media. You stream your favourite video game or publish your everyday makeup routine and, voilà, just by making your daily routines and hobbies publicly available, you become a star. In reality the content production of social media stars consumes a lot of time. According to the study of Zabel et al. (2017), German commercial YouTubers invest 26.2 hours per week on average in the production of content only, not counting administrative work (as e.g. networking with advertising partners, agencies or 
partner accounts). In addition to the invested time, the stars also need to handle the publicity and the pressure of constant upload necessity. To succeed in the long run, build and maintain an audience, it is vital to constantly create new content and have the creativity or expertise to do so. The initial investment to reach attention and generate traffic is mandatory, even if it takes years to become famous. As discussed in chapter 0 , the talent of social media stars is multidimensional and varies between different categories. Not only the core talent (e.g. skills of a gamer in the gaming sector), but also additional skills like entertaining talent and technical/digital skills are necessary. Being a social media star requires the robustness to put yourself into public, create your own content and publish your ideas. The constant demand for further content needs to be fed in order to succeed in the long run. Thus, it seems not likely that every "ordinary" person combines all qualities which are necessary to become a social media star. Not only the core talent and personality, but also the determination and commitment to constantly feed the audience are required. That is why we follow Turner's argumentation: "It is important to remember that celebrity still remains a systematically hierarchical and exclusive category, no matter how much it proliferates" (Turner 2006: 157).

\section{References}

Acquisti, Alessandro \& Varian, Hal R. (2005), Conditioning Prices on Purchase History, in: Marketing Science, Vol. 24 (3), pp. 267-381.

Acquisti, Alessandro, Taylor, Curtis R. \& Wagman, Liad (2016), The Economics of

Privacy, in: Journal of Economic Literature, Vol. 54 (2), pp. 442-492.

Adler, Moshe (1985), Stardom and Talent, in: American Economic Review, Vol. 75 (1), pp. 208-212.

Adler, Moshe (2006), Stardom and Talent, in: Victor A. Ginsburgh \& David Throsby, Handbook of the Economics of Art and Culture, Amsterdam; Boston: Elsevier, pp. 896-905.

Amegashie, J. Atsu (2009), American Idol: Should It Be a Singing Contest or a Popularity Contest, in: Journal of Cultural Economics, Vol. 33 (4), pp. 265-277. 
Anderson, Simon P. \& Gabszewicz, Jean J. (2006), The Media and Advertising: A Tale of Two-Sided Markets, in: Handbook of the Economics of Art and Culture, Vol. 1, Amsterdam: Elsevier, pp. 567-614.

Armstrong, Mark (2006), Competition in Two-Sided Markets, in: Rand Journal of Economics, Vol. 37 (3), pp. 668-691.

Audrezet, Alice, de Kerviler, Gwarlann \& Guidry Moulard, Julie (2018), Authenticity under threat: When social media influencers need to go beyond self-presentation, in: Journal of Business Research (online).

Becker, Gary S. (1965), A Theory of the Allocation of Time, in: The Economic Journal, Vol. 75 (299), pp. 493-517.

Belleflamme, Paul \& Peitz, Martin (2018), Inside the engine room of digital platforms: Reviews, ratings and recommendations, in: Juan José Ganuza and Gerard Llobet (eds.), Economic Analysis of the Digital Revolution, Funcas Social and Economic Studies, Nr. 4, Madrid: Funcas.

Benkler, Yochai (2006), The Wealth of Networks: How Social Production Transforms Markets and Freedom, New Haven: Yale University Press.

Blank, Grant (2013), Who creates content?, in: Information, Communication \& Society, Vol. 16 (4), pp. 590-612.

Boik, Andre, Greenstein, Shane M. \& Prince, Jeffrey (2017), The Empirical Economics of Online Attention, Kelley School of Business Research Paper No. 16-57.

Boorstin, Daniel J. (1961), The image or what happened to the American dream, New York: Harper and Row.

Borghans, Lex \& Groot, Loek (1998), Superstardom and Monopolistic Power: Why Media Stars Earn More Than Their Marginal Contributions to Welfare, in: Journal of Institutional and Theoretical Economics, Vol. 154 (3), pp. 546-571.

Borghol, Youmna, Ardon, Sebastien, Carlsson, Niklas, Eager, Derek \& Mahanti, Anirban (2012), The untold story of the clones: Content-agnostic Factors that Impact YouTube Video Popularity, in: Qiang Yang, Deepak Agarwal \& Jian Pei, KDD'12: The $18^{\text {th }}$ ACM SIGKDD International Conference on Knowledge Discovery and Data Mining, New York: ACM, pp. 1186-1194. 
Brown, Ian (2016), The economics of privacy, data protection and surveillance, in: Bauer, J. \& Latzer, M. (eds.), Handbook on the economics of the internet, Cheltenham: Edward Elgar, pp. 247-261.

Bruns, Axel (2008), Blogs, Wikipedia, Second Life, and Beyond: From Production to Produsage, New York: Peter Lang.

Bruns, Axel (2011), Gatekeeping, gatewatching, real-time feedback: new challenges for journalism, in: Brazilian Journalism Research Vol. 7 (2), pp. 117-136.

Bruns, Axel \& Highfield, Tim (2012), Blogs, Twitter, and breaking news: The produsage of citizen journalism, in: Rebecca Ann (ed.), Produsing Theory in a Digital World: The Intersection of Audiences and Production in Contemporary Theory, New York: Peter Lang, pp. 15-32.

Brynjolfsson, Erik \& Oh, Joo Hee (2012), The Attention Economy: Measuring the Value of Free Digital Services on the Internet, 33rd International Conference on Information Systems (ICIS).

Budzinski, Oliver \& Gaenssle, Sophia (2018), The Economics of Social Media Stars: An Empirical Investigation of Stardom, Popularity, and Success on YouTube, Ilmenau Discussion Papers, Vol. 24 (112).

Budzinski, Oliver, Kohlschreiber, Marie, Kuchinke, Björn A. \& Pannicke, Julia (2019), Does Music Quality Matter for Audience Voters in a Music Contest?, IImenau Economics Discussion Papers, Vol. 25 (122).

Budzinski, Oliver \& Kuchinke, Björn A. (2019), Industrial Organization of Media Markets and Competition Policy, in: Bjørn von Rimscha (ed.), Handbook Economics and Management of Media and Communication, Berlin: DeGruyter, forthcoming. Budzinski, Oliver \& Lindstädt-Dreusicke, Nadine (2018), The New Media Economics of Video-on-Demand Markets: Lessons for Competition Policy, Ilmenau Economics Discussion Papers, Vol. 24 (116).

Budzinski, Oliver, Noskova, Victoriia \& Zhang, Xijie (2018), The Brave New World of Digital Personal Assistants: Benefits and Challenges from an Economic Perspective, Ilmenau Economics Discussion Papers, Vol. 24 (118).

Budzinski, Oliver \& Stöhr, Annika (2018), Competition Policy Reform in Europe and Germany - Institutional Change in the Light of Digitization, in: European Competition Journal, Vol. 15 (1). 
Burgess, Jean \& Green, Joshua (2018), YouTube: Online Video and Participatory Culture, Cambridge/Malden: Polity.

Castells, Manuel (2009), Communication Power, Oxford: Oxford University Press.

Castillo, Michelle (2018), Pinterest nears \$1 billion in ad sales and valuation rises as it looks to go public in mid-2019, https://www.cnbc.com/2018/07/20/pinterestnearing-1-billion-in-ad-revenue-as-it-plans-to-ipo-mid-2019.html, accessed $19^{\text {th }}$ September 2018.

Chang, Yu-Ting, Yu, Hueij \& Lu, Hsi-Peng (2015), Persuasive messages, popularity cohesion, and message diffusion in social media marketing, in: Journal of Business Research, Vol. 68 (4), pp. 777-782.

Chatterjee, Laharee \& Aripaka, Pushkala (2018), IAC's Vimeo aims for \$100 million in revenue this year: CEO, https://www.reuters.com/article/us-iac-interactivevimeo/iacs-vimeo-aims-for-100-million-in-revenue-this-year-ceoidUSKCN1G71PN, accessed 19 th $^{\text {th }}$ September 2018.

Cowen, Tyler (2000), What Price Fame? Cambridge/London: Harvard University Press.

Dennhardt, Severin (2014), User-Generated Content and Its Impact on Branding, How User and Communities Create and Manage Brands in Social Media, Wiesbaden: Springer Gabler.

Detel, Hanne (2017), Netzprominenz: Entstehung, Erhaltung und Monetarisierung von Prominenz im digitalen Zeitalter, Köln: Herbert von Halem Verlag.

Dewenter, Ralf \& Rösch, Jürgen (2015), Einführung in die neue Ökonomie der Medienmärkte: Eine wettbewerbsökonomische Betrachtung aus Sicht der Theorie der zweiseitigen Märkte, Berlin: Springer.

Döring, Nicola (2014), Professionalisierung und Kommerzialisierung auf YouTube, in: merz medien + erziehung, Vol. 58 (4), pp. 24-31.

Evans, David S. (2013), Attention Rivalry Among Online Platforms, in: Journal of Competition Law and Economics, Vol. 9 (2), pp. 313-357.

Evans, David S. (2017), The Economics of Attention Markets, Working Paper, University College London.

Ezrachi, Ariel \& Stucke, Maurice E. (2015), Artificial Intelligence and Collusion: When Computers Inhibit Competition, University of Tennessee, Legal Studies Research Paper Series, (267). 
Ezrachi, Ariel \& Stucke, Maurice E. (2016a), How Pricing Bots Could Form Cartels and Make Things More Expensive, in: Harvard Business Review.

Ezrachi, Ariel \& Stucke, Maurice E. (2016b), Virtual Competition, Harvard University Press, Harvard.

Ezrachi, Ariel \& Stucke, Maurice E. (2017), Two Artificial Neural Networks Meet in an Online Hub and Change the Future (of Competition, Market Dynamics and Society), Oxford Legal Studies Research Paper No. 24/2017; University of Tennessee Legal Studies Research Paper No. 323.

Falkinger, Josef (2008), Limited Attention as a Scarce Resource in Information-Rich Economies, in: The Economic Journal, Vol. 118 (532), pp. 1596-1620.

Ferrara, Emilio (2015), Manipulation and abuse on social media, in: ACM SIGWEB Newsletter.

Ferrara, Emilio, Varol, Onur, Davis, Clayton, Menczer, Filippo \& Flammini, Alessandro (2016), The Rise of Social Bots, in: Communications of the ACM, Vol. 59 (7), pp. 96-104.

Forbes (2018), Top influencers, https://www.forbes.com/top-influencers/ \#51f47dfa72dd, accessed 19 $9^{\text {th }}$ September 2018.

Franck, Egon \& Nüesch, Stephan (2007), Avoiding 'Star Wars' - Celebrity Creation as Media Strategy, in: Kyklos, Vol. 60 (2), pp. 211-230.

Franck, Egon \& Nüesch, Stephan (2012), Talent and/or Popularity - What Does it Take to Be a Superstar?, in: Economic Inquiry, Vol. 50 (1), pp. 202-216.

Frank, Robert H. \& Cook, Philip J. (2013), Winner-Take-All Markets, in: Studies in Microeconomics, Vol. 1 (2), pp. 131-154.

Fuchs, Christian (2014), Digital prosumption labour on social media in the context of the capitalist regime of time, in: Time \& Society, Vol. 23 (1), pp. 97-123.

Gal, Michael S. \& Elkin-Koren, Niva (2017), Algorithmic Consumers, in: Harvard Journal of Law and Technology, Vol. 30, pp. 1-45.

Gamson, Joshua (1994), Claims of Fame. Celebrity in Contemporary America, Berkeley/LosAngeles/London: University of California Press.

Gergaud, Olivier, Ginsburgh, Victor \& Livat, Florine (2012), Success of Celebrities: Talent, Intelligence or Beauty?, in: Economics Bulletin 32 (4), pp. 3120-3127. 
Ghose, Anindya \& Yang, Sha (2009), An empirical analysis of search engine advertising: Sponsored search in electronic markets, in: Management Science, Vol. 55 (10), pp. 1605-1622.

Google (2016), YouTube Creators-Studie: Glaubwürdig, authentisch, nahbar, https://www.thinkwithgoogle.com/intl/de-de/marketingkanaele/youtube/ youtube-creators-studie-glaubwurdig-authentisch-nahbar-1456243916/, accessed $28^{\text {th }}$ November 2018.

Google (2018), How to earn money from your videos, https://support.google.com/youtube/answer/72857?hl=en, accessed $21^{\text {st }}$ November 2018.

Goolsbee, Austan \& Klenow, Peter J. (2006), Valuing Consumer Products by the Time Spent Using Them: An Application to the Internet, in: American Economic Review Papers \& Proceedings, Vol. 96 (2), pp. 108-113.

Grabs, Anne \& Bannour, Karim-Patrick (2016), Follow me! Erfolgreiches Social Media Marketing mit Facebook, Twitter und Co., 2. Aufl., Bonn: Galileo Computing. Hamlen, William (1991), Superstardom in Popular Music: Empirical Evidence, in: Review of Economics and Statistics, Vol 73 (4), pp. 729-733.

Hartley, John (1999), Uses of Television, London: Routledge.

Haucap, Justus \& Stühmeier, Torben (2016), Competition and Antitrust in Internet Markets, in: Johannes M. Bauer \& Michael Latzer (eds.), Handbook on the Economics of the Internet, Cheltenham: Edward Elgar, pp. 183-210.

Honsel, Jan (2018), Übersicht aktueller Social Network Statistiken, https://socialmedia-institute.com/uebersicht-aktueller-social-media-nutzerzahlen/, accessed 19th September 2018.

Instagram (2018), kayla_itsines, https://www.instagram.com/kayla itsines/, accessed $11^{\text {th }}$ July 2018.

Jenkins, Henry (2006), Convergence Culture: Where old and new media collide, New York: NYU press.

Jenkins, Henry, Ford, Sam \& Green, Joshua (2012), Spreadable Media: Creating value and meaning in a networked culture, New York: NYU Press.

Jin, Seung-A Annie \& Phua, Joe (2014), Following Celebrities' Tweets About Brands: The Impact of Twitter-Based Electronic Word-of-Mouth on Consumers' Source 
Credibility Perception, Buying Intention, and Social Identification With Celebrities, in: Journal of Advertising, Vol. 43 (2), pp. 181-195.

Kahn, Lawrence M. (2000), The Sports Business as a Labor Market Laboratory, in: Journal of Economic Perspectives, Vol. 14 (3), pp. 75-94.

Kaplan, Andreas M. \& Haenlein, Michael (2010), Users of the world, unite! The challenges and opportunities of Social Media, in: Business Horizons, Vol. 53 (1), pp. 59-68.

Kim, Jin (2012), The institutionalization of YouTube: From user-generated content to professionally generated content, in: Media, Culture \& Society, Vol. 34 (1), pp. 5367.

Krueger, A. B. (2005), The Economics of Real Superstars: the Market for Rock Concerts in the Material World, in: Journal of Labor Economics, Vol. 23 (1), pp. 1-30.

Leibenstein, Harvey (1950), Bandwagon, Snob, and Veblen Effects in the Theory of Con-sumers' Demand, in: Quarterly Journal of Economics, Vol. 64 (2), pp. 183207.

MacDonald, Glenn M. (1988), The Economics of Rising Stars, in: American Economic Review, Vol. 78 (1), pp. 155-166.

Marshall, P. David (1997), Celebrity and Power: Fame in Contemporary Culture, Minneapolis/London: University of Minnesota Press.

Marwick, Alice E. (2010), Status update: Celebrity, publicity, and self branding in Web 2.0, New York University, New York.

Marwick, Alice E. (2015), You May Know Me From YouTube: (Micro)-Celebrity in Social Media, in: Marshall, David \& Redmond, Sean (eds.), A Companion to Celebrity, Chichester: John Wiley \& Sons Inc, pp. 333-350.

Mehra, Salil K. (2015), Antitrust and the Robo-Seller: Competition in the Time of Algorithms, in: Minnesota Law Review, Vol. 100 (4), pp. 1323-1375.

Molthagen-Schnörin, Stefanie (2017), Digitale Medien - medialer Wandel und der Einfluss auf Textsorten und Sprache, in: Susanne Femers-Koch, Stefanie Molthagen-Schnöring (eds.), Textspiele in der Wirtschaftskommunikation, Wiesbaden: Springer VS, pp. 73-109. 
Morreale, Joanne (2014), From Homemade to Store Bought: Annoying Orange and the Professionalization of YouTube, in: Journal of Consumer Culture, Vol. 14 (1), pp. 113-128.

Nouri, Melody (2018), The Power of Influence: Traditional Celebrity vs Social Media Influencer, Advanced Writing: Pop Culture Intersections.

OECD (2007), Participative web and user-created content: Web 2.0, wikis, and social networkin, Paris: Organisation for Economic Co-operation and Development.

Oxera (2017), When Algorithms Set Prices: Winners and Losers, https://www.regulation.org.uk/library/2017-Oxera-When_algorithms_set_priceswinners_and_losers.pdf, accessed 22 ${ }^{\text {nd }}$ August 2018.

Pasquale, Frank (2016), The Black Box Society: The Secret Algorithms that Control Money and Information, Harvard University Press, Harvard.

Pauriol, Elise (2017), Benchmark Study Q1 2017 - Current Social Media Trends, https://www.quintly.com/blog/social-media-benchmark-study, accessed $20^{\text {th }}$ March 2019.

Ritzer, George \& Jurgenson, Nathan (2010), Production, Consumption, Prosumption: The Nature of Capitalism in the Age of the Digital Prosumer, Journal of Consumer Culture, Vol. $10(1)$, pp. 13-36.

Robehmed, Natalie \& Berg, Madeline (2018), Forbes: The Highest-Paid YouTube Stars 2018, https://www.forbes.com/sites/natalierobehmed/2018/12/03/highest-paidyoutube-stars-2018-markiplier-jake-paul-pewdiepie-and-more/\#8ef0a90909ac, accessed $19^{\text {th }}$ March 2019.

Rochet, Jean-Charles \& Tirole, Jean (2003), Platform Competition in Two-Sided Markets, in: Journal of the European Economic Association, Vol. 1 (4), pp. 9901029.

Rochet, Jean-Charles \& Tirole, Jean (2006), Two-Sided Markets: A Progress Report, in: Rand Journal of Economics, Vol. 37 (3), pp. 645-667.

Roß, Wiebke \& Weghake, Jens (2015), 10 Jahre YouTube - Von dem Aufstieg einer Plattform und der Entwicklung neuer Märkte zum Kollateralschaden einer GoogleRegulierung? in: Ordo - Jahrbuch für die Ordnung von Wirtschaft und Gesellschaft, Vol. 66, pp. 195-220. 
Romer, David (2006), Do firms maximize? Evidence from professional football, in: Journal of Political Economy, Vol. 114 (2), pp. 340-365.

Rosen, Sherwin (1981), The Economics of Superstars, in: American Economic Review, Vol. 71 (5), pp. 845-858.

Rosen, Sherwin \& Sanderson, Allen (2001), Labour markets in professional sports, in: The Economic Journal, Vol. 111 (469), pp. 47-68.

Schulze, Günther G. (2003), Superstars, in: Ruth Towse (ed.), A Handbook of Cultural Economics, Cheltenham: Elgar, pp. 431-436.

Schwalbe, Ulrich (2018), Algorithms, Machine Learning, and Collusion, Hohenheim Discussion Papers.

Senft, Theresa M. (2008), Camgirls: Celebrity and Community in the Age of Social Networks, New York: Lang.

Shirky, Clay (2008), Here Comes Everybody: The Power of Organizing Without Organizations, New York: Penguin.

Shirky, Clay (2011), Political power of social media. Technology, the public sphere, and political change, in: Foreign Affairs, Vol. 90 (1), pp. 28-40.

Simon, Herbert (1971), Designing Organizations for an Information-Rich World, in: Martin, Greenberger (ed.), Computers, communications, and the public interest, Baltimore: The John Hopkin University Press, pp. 37-72.

Singer, Jane (2010), Quality Control: Perceived Effects of User-Generated Content on Newsroom Norms, Values and Routines, in: Journalism Practice, Vol. 4 (2), pp. $127-142$.

Socialblade (2017), Top 250 YouTube Networks, https://web.archive.org/web/20171122220815/https://socialblade.com/youtube/t op/networks/most-subscribed, accessed 22 ${ }^{\text {nd }}$ November 2018.

Socialblade (2018), Top 250 YouTubers Games Channels sorted by Subscribers, https://socialblade.com/youtube/top/category/games/mostsubscribed, accessed $6^{\text {th }}$ June 2018

Stigler, George J. \& Becker, Gary S. (1977), De Gustibus Non Est Disputandum, in: American Economic Review, Vol. 67 (2), pp. 76-90.

Toffler, Alvin (1980), The Third Wave. New York: William Morrow. 
Turner, Fred (2006), From Counterculture to Cyberculture: Stewart Brand, the Whole Earth Network, and the Rise of Digital Utopianism, Chicago: Chicago University Press.

Turner, Graeme (2004), Understanding Celebrity. London: Sage.

Veirman, M. D., Cauberghe, V. \& Hudders, L. (2017), Marketing through Instagram influencers: the impact of number of followers and product divergence on brand attitude, in: International Journal of Advertising, Vol. 36 (5), pp. 798-828.

Vimeo (2018), About, https://vimeo.com/de/about, accessed 19 ${ }^{\text {th }}$ September 2018. Woodcock, Ramsi (2017), The Bargaining Robot, in: CPI Antitrust Chronicle.

Winkler, Rolfe (2015), YouTube: 1 Billion Viewers, No Profit, https://www.wsj.com/articles/viewers-dont-add-up-to-profit-for-youtube1424897967, accessed 19 ${ }^{\text {th }}$ September 2018.

Winkler, Rolfe, Nicas, Jack \& Fritz, Ben (2017), Disney Severs Ties With YouTube Star PewDiePie After Anti-Semitic Posts, https://www.wsj.com/articles/disney-seversties-with-youtube-star-pewdiepie-after-anti-semitic-posts-1487034533, accessed $4^{\text {th }}$ December 2018.

Wuttig, Marcel-André (2018), Neue Statistik beweist: Twitch war 2017 erfolgreicher als YouTube, https://www.giga.de/webapps/twitch/news/neue-statistik-beweisttwitch-war-2017-erfolgreicher-als-youtube/, accessed 19 ${ }^{\text {th }}$ September 2018.

Xiao, Min, Wang, Rang \& Chan-Olmsted, Sylvia (2018), Factors Affecting YouTube Influencer Marketing Credibility: A Heuristic-Systematic Model, in: Conference Papers World Media Economics and Management Conference.

YouTube (2018a), DanTDM, https://www.youtube.com/user/TheDiamondMinecart, accessed $11^{\text {th }}$ July 2018.

YouTube (2018b), YouTube Creators, https://www.youtube.com/user/ creatoracademy, accessed $22^{\text {nd }}$ August 2018.

Zabel, Christian, Seemann, Christian \& Pagel, Sven (2017), Youtube-Creators in Deutschland - Motive, Produktionsroutinen und Finanzierung von deutschen Online-Video-Produzenten, in: Wolfgang Seufert (ed.), Media Economics revisited: (Wie) Verändert das Internet die Ökonomie der Medien?, Baden-Baden: Nomos, pp. $125-145$. 


\section{Appendix}

Table 4: Overview Content Communities

\begin{tabular}{|c|c|c|c|c|c|}
\hline Platform & $\begin{array}{c}\text { Parent Com- } \\
\text { pany }\end{array}$ & $\begin{array}{c}\text { Estimated } \\
\text { Revenue/ Prof- } \\
\text { its }\end{array}$ & $\begin{array}{l}\text { Content Up- } \\
\text { loads }\end{array}$ & Active Users & $\begin{array}{c}\text { Number of Top } \\
\text { Stars }^{21}\end{array}$ \\
\hline YouTube & Google LLC & $\begin{array}{l}\text { Estimated reve- } \\
\text { nue (world- } \\
\text { wide) } \\
\text { 2014: USD } 4 \\
\text { billion } \\
\text { 2015: USD } 6 \\
\text { billion } \\
\text { Digital ads } \\
\text { 2016: USD } 2.92 \\
\text { billion } \\
\text { (Prediction } \\
\text { 2018: USD } 4.43 \\
\text { billion) }\end{array}$ & $\begin{array}{l}400 \text { videos } / \mathrm{h} \\
(2015)\end{array}$ & $\begin{array}{l}1.9 \mathrm{~m} / \text { month } \\
(2019)\end{array}$ & $\begin{array}{l}\text { Total: } 46 \\
\text { Tech: } 6 \\
\text { Food: } 4 \\
\text { Home: } 1 \\
\text { Beauty: } 7 \\
\text { Fitness. } 1 \\
\text { Gaming: } 8 \\
\text { Travel: } 2 \\
\text { Entertainment. } 7 \\
\text { Parenting: } 1 \\
\text { Fashion: } 1 \\
\text { Kids. } 8\end{array}$ \\
\hline Vimeo & $\begin{array}{l}\text { InterAc- } \\
\text { tiveCorp }\end{array}$ & $\begin{array}{l}\text { Sales target } \\
\text { 2019: USD } 100 \\
\text { million }\end{array}$ & & $\begin{array}{l}80 \mathrm{~m} / \text { total } \\
(2018)\end{array}$ & Total: 0 \\
\hline Twitch & $\begin{array}{l}\text { Ama- } \\
\text { zon.com, Inc. } \\
\text { (Twitch Inter- } \\
\text { active, Inc.) }\end{array}$ & $\begin{array}{l}\text { Estimated reve- } \\
\text { nue (world- } \\
\text { wide) } \\
\text { 2017: USD } 1.7 \\
\text { billion }\end{array}$ & & $\begin{array}{l}550,530 / \text { month } \\
(2017)\end{array}$ & $\begin{array}{l}\text { Total: } 2 \\
\text { Gaming: } 2\end{array}$ \\
\hline MySpace & Time Inc. & $\begin{array}{l}\text { Digital ads } \\
\text { 2010: USD } 274 \\
\text { million }\end{array}$ & & $\begin{array}{l}\text { 13.32m/total } \\
\text { (USA, 2016) }\end{array}$ & $\begin{array}{l}\text { Total: } 1 \\
\text { Beauty. } 1\end{array}$ \\
\hline $\begin{array}{l}\text { Insta- } \\
\text { gram }\end{array}$ & Facebook Inc. & $\begin{array}{l}\text { Digital ads in } \\
\text { the US: } \\
\text { 2016: USD } 1.61 \\
\text { billion } \\
\text { (Prediction } \\
\text { 2018: USD } 5.4 \\
\text { billion) }\end{array}$ & $\begin{array}{l}\text { 95m pics/day } \\
(2016)\end{array}$ & $\begin{array}{l}1.0 \mathrm{~m} / \text { month } \\
(2019)\end{array}$ & $\begin{array}{l}\text { Total: } 13 \\
\text { Home: } 2 \\
\text { Beauty: } 2 \\
\text { Fitness. } 5 \\
\text { Travel: } 1 \\
\text { Entertainment: } 1 \\
\text { Parenting: } 1 \\
\text { Fashion: } 1\end{array}$ \\
\hline Pinterest & $\begin{array}{l}\text { Cold Brew } \\
\text { Labs, Inc. }\end{array}$ & $\begin{array}{l}\text { Estimated reve- } \\
\text { nue (world- } \\
\text { wide): } \\
\text { 2017: USD } 500 \\
\text { million }\end{array}$ & & $\begin{array}{l}200 \mathrm{~m} / \text { month } \\
(2017)\end{array}$ & $\begin{array}{l}\text { Total: } 1 \\
\text { Home: } 1\end{array}$ \\
\hline
\end{tabular}

21 According to Forbes' (2018) top ten rankings per category (excluding pets, private blogs and vlogs). 


\begin{tabular}{|c|c|c|c|c|c|}
\hline Twitter & Twitter Inc. & $\begin{array}{l}\text { Estimated reve- } \\
\text { nue (world- } \\
\text { wide): } \\
\text { 2017: USD } \\
2.443 \text { million } \\
\text { Losses (world- } \\
\text { wide): } \\
\text { 2017: USD } \\
\text { 108.06 million }\end{array}$ & $\begin{array}{l}500 m \\
\text { tweets/day } \\
(2015) \\
6000 \text { tweets/s } \\
(2017)\end{array}$ & $\begin{array}{l}335 \mathrm{~m} / \text { month } \\
(2018)\end{array}$ & $\begin{array}{l}\text { Total: } 4 \\
\text { Tech: } 3 \\
\text { Fitness. } 1\end{array}$ \\
\hline Tumblr & $\begin{array}{l}\text { Oath Inc. } \\
\text { (Until 2017: } \\
\text { Yahoo) }\end{array}$ & & $\begin{array}{l}163.1 \mathrm{~b} \\
\text { posts/total } \\
(2018)\end{array}$ & $\begin{array}{l}357 \mathrm{~m} / \text { month } \\
\text { (2017) }\end{array}$ & Total: 0 \\
\hline
\end{tabular}

Sources: (Castillo 2018, Chatterjee \& Aripaka 2018, Honsel 2018, Vimeo 2018, Winkler 2015, Wuttig 2018) 


\section{Diskussionspapiere aus dem Institut für Volkswirtschaftslehre der Technischen Universität IImenau}

Nr. 69 Budzinski, Oliver: Empirische Ex-Post Evaluation von wettbewerbspolitischen Entscheidungen: Methodische Anmerkungen, Januar 2012.

Nr. 70 Budzinski, Oliver: The Institutional Framework for Doing Sports Business: Principles of EU Competition Policy in Sports Markets, January 2012.

Nr. 71 Budzinski, Oliver; Monostori, Katalin: Intellectual Property Rights and the WTO, April 2012.

Nr. 72 Budzinski, Oliver: International Antitrust Institutions, Juli 2012.

Nr. 73 Lindstädt, Nadine; Budzinski, Oliver: Newspaper vs. Online Advertising - Is There a Niche for Newspapers in Modern Advertising Markets?

Nr. 74 Budzinski, Oliver; Lindstädt, Nadine: Newspaper and Internet Display Advertising - Co-Existence or Substitution?, Juli 2012b.

Nr. 75 Budzinski, Oliver: Impact Evaluation of Merger Control Decisions, August 2012.

Nr. 76 Budzinski, Oliver; Kuchinke, Björn A.: Deal or No Deal? Consensual Arrangements as an Instrument of European Competition Policy, August 2012.

Nr. 77 Pawlowski, Tim, Budzinski, Oliver: The (Monetary) Value of Competitive Balance for Sport Consumers, Oktober 2012.

Nr. 78 Budzinski, Oliver: Würde eine unabhängige europäische Wettbewerbsbehörde eine bessere Wettbewerbspolitik machen?, November 2012.

Nr. 79 Budzinski, Oliver; Monostori, Katalin; Pannicke, Julia: Der Schutz geistiger Eigentumsrechte in der Welthandelsorganisation - Urheberrechte im TRIPS Abkommen und die digitale Herausforderung, November 2012.

Nr. 80 Beigi, Maryam H. A.; Budzinski, Oliver: On the Use of Event Studies to Evaluate Economic Policy Decisions: A Note of Caution, Dezember 2012.

Nr. 81 Budzinski, Oliver; Beigi, Maryam H. A.: Competition Policy Agendas for Industrializing Countries, Mai 2013. 
Nr. 82 Budzinski, Oliver; Müller, Anika: Finanzregulierung und internationale Wettbewerbsfähigkeit: der Fall Deutsche Bundesliga, Mai 2013.

Nr. 83 Doose, Anna Maria: Methods for Calculating Cartel Damages: A Survey, Dezember 2013.

Nr. 84 Pawlowski, Tim; Budzinski, Oliver: Competitive Balance and Attention Level Effects: Theore-tical Considerations and Preliminary Evidence, März 2014.

Nr. 85 Budzinski, Oliver: The Competition Economics of Financial Fair Play, März 2014.

Nr. 86 Budzinski, Oliver; Szymanski, Stefan: Are Restrictions of Competition by Sports Associations Horizontal or Vertical in Nature?, März, 2014.

Nr. 87 Budzinski, Oliver: Lead Jurisdiction Concepts Towards Rationalizing Multiple Competition Policy Enforcement Procedures, Juni 2014.

Nr. 88 Budzinski, Oliver: Bemerkungen zur ökonomischen Analyse von Sicherheit, August 2014.

Nr. 89 Budzinski, Oliver; Pawlowski, Tim: The Behavioural Economics of Competitive Balance: Implications for League Policy and Championship Management, September 2014.

Nr. 90 Grebel, Thomas; Stuetzer, Michael: Assessment of the Environmental Performance of European Countries over Time: Addressing the Role of Carbon, September 2014.

Nr. 91 Emam, Sherief; Grebel, Thomas: Rising Energy Prices and Advances in Renewable Energy Technologies, July 2014.

Nr. 92 Budzinski, Oliver; Pannicke, Julia: Culturally-Biased Voting in the Eurovision Song Contest: Do National Contests Differ?, December 2014.

Nr. 93 Budzinski, Oliver; Eckert, Sandra: Wettbewerb und Regulierung, März 2015.

Nr. 94 Budzinski, Oliver; Feddersen, Arne: Grundlagen der Sportnachfrage: Theorie und Empirie der Einflussfaktoren auf die Zuschauernachfrage, Mai 2015.

Nr. 95 Pannicke, Julia: Abstimmungsverhalten im Bundesvision Song Contest: Regionale Nähe versus Qualität der Musik, Oktober 2015.

Nr. 96 Budzinski, Oliver; Kretschmer, Jürgen-Peter: Unprofitable Horizontal Mergers, External Effects, and Welfare, October 2015. 
Nr. 97 Budzinski, Oliver; Köhler, Karoline Henrike: Is Amazon The Next Google?, October 2015.

Nr. 98 Kaimann, Daniel; Pannicke, Julia: Movie success in a genre specific contest: Evidence from the US film industry, December 2015.

Nr. 99 Pannicke, Julia: Media Bias in Women's Magazines: Do Advertisements Influence Editorial Content?, December 2015.

Nr. 100 Neute, Nadine; Budzinski, Oliver: Ökonomische Anmerkungen zur aktuellen Netzneutralitätspolitik in den USA, Mai 2016.

Nr. 101 Budzinski, Oliver; Pannicke, Julia: Do Preferences for Pop Music Converge across Countries? - Empirical Evidence from the Eurovision Song Contest, Juni 2016.

Nr. 102 Budzinski, Oliver; Müller-Kock, Anika: Market Power and Media Revenue Allocation in Professonal Sports: The Case of Formula One, Juni 2016.

Nr. 103 Budzinski, Oliver: Aktuelle Herausforderungen der Wettbewerbspolitik durch Marktplätze im Internet, September 2016.

Nr. 104 Budzinski, Oliver: Sind Wettbewerbe im Profisport Rattenrennen?, Februar 2017.

Nr. 105 Budzinski, Oliver; Schneider, Sonja: Smart Fitness: Ökonomische Effekte einer Digitalisierung der Selbstvermessung, März 2017.

Nr. 106 Budzinski, Oliver; Pannicke, Julia: Does Popularity Matter in a TV Song Competition? Evidence from a National Music Contest, April 2017.

Nr. 107 Budzinski, Oliver; Grusevaja, Marina:Die Medienökonomik personalisierter Daten und der Facebook-Fall, April 2017.

Nr. 108 Budzinski, Oliver: Wettbewerbsregeln für das Digitale Zeialter - Die Ökonomik personalisierter Daten, Verbraucherschutz und die 9.GWB-Novelle, August 2017.

Nr. 109 Budzinski, Oliver: Four Cases in Sports Competition Policy: Baseball, Judo, Football, and Motor Racing, September 2017.

Nr. 110 Budzinski, Oliver: Market-internal Financial Regulation in Sports as an Anticompetitive Institution, October 2017.

Nr. 111 Bougette, Patrice; Budzinski, Oliver; Marty, Frédéric: EXPLOITATIVE ABUSE AND ABUSE OF ECONOMIC DEPENDENCE: WHAT CAN WE LEARN FROM THE INDUSTRIAL ORGANIZATION APPROACH?, December 2017. 
Nr. 112 Budzinski, Oliver; Gaenssle, Sophia: The Economics of Social Media Stars: An Empirical Investigation of Stardom, Popularity, and Success on YouTube, Januar 2018.

Nr. 113 Gaenssle, Sophia; Budzinski, Oliver; Astakhova Daria: Conquering the Box Office: Factors, influencing Success of International Movies in Russia, Mai 2018.

Nr. 114 Budzinski, Oliver; Stöhr, Annika: Die Ministererlaubnis als Element der deutschen Wettbewerbsordnung: eine theoretische und empirische Analyse, Juli 2018.

Nr. 115 Budzinski, Oliver; Kuchinke, Björn A.: Modern Industrial Organization Theory of Media Markets and Competition Policy Implications, September 2018.

Nr. 116 Budzinski, Oliver; Lindstädt-Dreusicke, Nadine: The New Media Economics of Video-on-Demand Markets: Lessons for Competition Policy, Oktober 2018.

Nr. 117 Budzinski, Oliver; Stöhr, Annika: Competition Policy Reform in Europe and Germany - Institutional Change in the Light of Digitization, November 2018.

Nr. 118 Budzinski, Oliver; Noskova, Victoriia; Zhang, Xijie: The Brave New World of Digital Personal Assistants: Benefits and Challenges from an Economic Perspective, December 2018.

Nr. 119 Bougette, Patrice; Budzinski, Oliver \& Marty, Frédéric: EXPLOITATIVE ABUSE AND ABUSE OF ECONOMIC DEPENDENCE: WHAT CAN WE LEARN FROM AN INDUSTRIAL ORGANIZATION APPROACH? [Updated Version 2018], December 2018.

Nr. 120 Bartelt, Nadja: Bundling in Internetmärkten - Ökonomische Besonderheiten, Wettbewerbseffekte und Regulierungsimplikationen, Dezember 2018.

Nr. 121 Budzinski, Oliver; Feddersen, Arne: Measuring Competitive Balance in Formula One Racing, März 2019.

Nr. 122 Budzinski, Oliver; Kohlschreiber, Marie; Kuchinke, Björn A. \& Pannicke, Julia: Does Music Quality Matter for Audience Voters in a Music Contest, März 2019. 